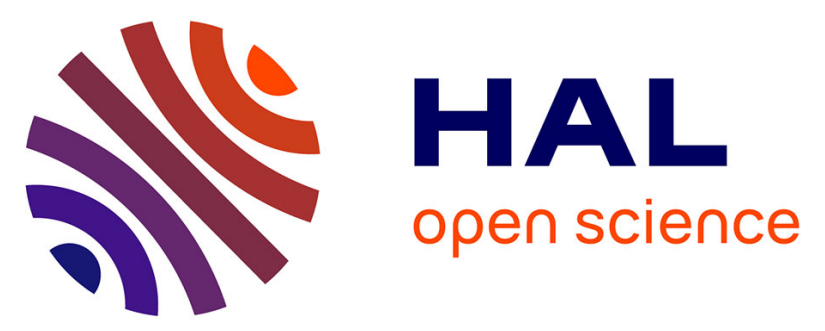

\title{
Constraints on Moho Depth and Crustal Thickness in the Liguro-Provençal Basin from a 3d Gravity Inversion : Geodynamic Implications
}

J. M. Gaulier, N. Chamot-Rooke, F. Jestin

\section{- To cite this version:}

J. M. Gaulier, N. Chamot-Rooke, F. Jestin. Constraints on Moho Depth and Crustal Thickness in the Liguro-Provençal Basin from a 3d Gravity Inversion: Geodynamic Implications. Revue de l'Institut Français du Pétrole, 1997, 52 (6), pp.557-583. 10.2516/ogst:1997060 . hal-02079135

\section{HAL Id: hal-02079135 \\ https://hal-ifp.archives-ouvertes.fr/hal-02079135}

Submitted on 25 Mar 2019

HAL is a multi-disciplinary open access archive for the deposit and dissemination of scientific research documents, whether they are published or not. The documents may come from teaching and research institutions in France or abroad, or from public or private research centers.
L'archive ouverte pluridisciplinaire HAL, est destinée au dépôt et à la diffusion de documents scientifiques de niveau recherche, publiés ou non, émanant des établissements d'enseignement et de recherche français ou étrangers, des laboratoires publics ou privés.

\section{(c)(1)}

Distributed under a Creative Commons Attribution| 4.0 International License 


\section{CON STRAIN TS ON MOHO DEPTH AN D CRUSTALTHIC KN ESS IN THE UG URO -PRO VEN CCAL BASIN FROM A 3D G RAVITY IN VERSIO N: G EO DYN AM IC IM PUC ATIO N S*}

\section{N. CHAMOT-ROOKE and F. JESTIN}

Laboratoire de G éologie ${ }^{1}$

\section{J.-M. GAULIER}

Institut français du pétrole ${ }^{2}$
(1) CNRS-URA 1316, École normale supérieure 24 rue Lhomond,

75231 Paris Cedex 05 - France

(2) 1 et 4 , avenue de Bois-Préau,

92852 Rueil-Malmaison Cedex - France

* This article will be published in: Bulletin de la société géologique de Londres, volume spécial IBS, B. Durand Ed.

\section{CONTRAINTES SUR LA PROFONDEUR DU MOHO ET L'ÉPAISSEUR CRUSTALE DANS LE BASSIN LIGURO-PROVENÇAL À PARTIR DE L'INVERSION 3D DE DONNÉES GRAVIMÉTRIQUES : IMPLICATIONS GÉODYNAMIQUES}

Ce rapport présente un travail commun avec le Laboratoire de géodynamique de l'École normale supérieure (ENS). Ce travail doit être resitué dans son contexte : l'étude régionale du golfe du Lion a été possible dans le cadre du projet européen Integrated Basin Studies. Le développement du code d'inversion 3D avait fait l'objet de conventions avec l'ENS pendant les années précédentes. La mise en œuvre d'une telle inversion est désormais possible à l'IFP. II n'y a pas d'interface pour ce calculateur. L'aide des collègues de I'ENS est souhaitable pour la mise en forme des données.

II a paru opportun, compte tenu des délais imprévus de publication du volume du BSGL* pour lequel cet article a été accepté, de montrer l'existence et les potentialités de cette méthode. II est vraisemblable qu'elle pourra être un apport significatif à l'étude des marges passives et plus particulièrement dans le cas des études concernant l'offshore profond. Elle a déjà retenu l'attention de plusieurs collègues de l'industrie pétrolière.

\section{CONSTRAINTS ON MOHO DEPTH AND CRUSTAL THICKNESS IN THE LIGURO-PROVENÇAL BASIN FROM A 3D GRAVITY INVERSION: GEODYNAMIC IMPLICATIONS}

3D gravity modelling is combined with seismic refraction and reflection data to constrain a new Moho depth map in the LiguroProvençal Basin (Western Mediterranean Sea). At seismically controlled points, the misfit between the gravimetric solution and the seismic data is about $2 \mathrm{~km}$ for a range of Moho depth between $12 \mathrm{~km}$ (deep basin) and $30 \mathrm{~km}$ (mainlands). The oceanic crust thickness in the deep basin $(5 \mathrm{~km})$ is smaller than the average oceanic crust thickness reported in open oceans $(7 \mathrm{~km})$, pointing to a potential mantle temperature $30^{\circ} \mathrm{C}$ to $50^{\circ} \mathrm{C}$ below normal and/or very slow oceanic spreading rate. Oceanic crust thickness is decreasing towards the Ligurian Sea and towards the 
continent-ocean boundary to values as small as $2 \mathrm{~km}$. Poor magma supply is a result of low potential mantle temperature at depth, lateral thermal conduction towards unextended continental margin, and decrease of the oceanic spreading rate close to the pole of opening in the Ligurian Sea. Re-examination of magnetic data (paleomagnetic data and magnetic lineations) indicates that opening of the Liguro-Provençal Basin may have ceased as late as Late Burdigalian $(16.5 \mathrm{Ma})$ or even later. The absence of significant time gap between cessation of opening in the LiguroProvençal Basin and rifting of the Tyrrhenian domain favours a continuous extension mechanism since Upper Oligocene driven by the African trench retreat.

\section{ESFUERZOS EN PROFUNDIDAD DEL MOHO Y EL ESPESOR CRUSTAL EN LA CUENCA LIGURO- PROVENZAL A PARTIR DE LA INVERSIÓN 3D DE DATOS GRAVIMÉTRICOS : IMPLICACIONES GEODINÁMICAS.}

En este informe se presenta un trabajo común llevado a cabo conjuntamente con el Laboratorio de geodinámica de la Escuela Normal Superior (ENS). Este trabajo se debe restituir en su contexto propio : el estudio regional del Golfo de León ha resultado posible en el marco del proyecto europeo Integrated Basin Estudies. El desarrollo del código de inversión 3D fue objeto de convenciones con la ENS durante los años precedentes. La implementación de semejante inversión resulta ahora posible por parte del IFP. No existe ningún interfaz para este calculador. La ayuda de los colegas de la ENS es deseable para la conformación de los datos.

Habida cuenta de los plazos imprevistos para la publicación del volumen del BSGL, para el cual se ha aceptado este artículo, ha parecido oportuno mostrar su existencia, así como las potencialidades de este método. Parece verosímil que podrá de este modo, constituir una aportación significativa para el estudio de los márgenes pasivos y, en particular, en el caso de los estudios costafuera profundos. Su contenido ha sido objeto de atención por parte de varios colegas de la industria petrolera.

\section{INTRODUCTION}

Determination of the deep structure across continental margins has been one of the major goals achieved through deep seismic profiling in the recent years. Two kinds of deep-seismic soundings have been obtained so far across the Gulf of Lion margin and adjacent deep basin: multichannel seismics of ECORS type and wide-angle refraction data using the two-ships Expanding Spread Profile technique. Both techniques are complementary, since multichannel profiles image the main structures along a section of the basin, from the surface to Moho depth, while ESP's constrain the 1 -D velocity structure at some spots along the section. Deep-reflection and refraction techniques were particularly successful in reaching the crust-mantle discontinuity (Moho) in the Gulf of Lion area. However, seismic data remain sparse. Variability of the crustal structure is high, both across the margins (from unstretched continental crust to oceanic crust) and along (for instance from smoothly stretched Gulf of Lion margin to sharply stretched Provençal margin). The oceanic crust thickness in the deeper part of the basin is also highly variable. The deep structure of the basin is thus complex, preventing reliable extrapolation from sparse seismic data.

Gravity data can be used to obtain a reliable geometry of the Moho discontinuity in regions where no further information is available. The triangular shape of the Liguro-Provençal Basin requires 3D gravity inversion. The use of Fourier transforms to invert for the shape of the Moho is briefly described. Seismic Moho data are then used to determine free parameters in the inversion and to control the validity of the gravimetric solution. The new Moho depth and crustal thickness maps are finally used to discuss some of the geodynamic implications.

\section{ESTABLISHING A NEW MOHO DEPTH MAP FROM 3D GRAVITY INVERSION}

\subsection{Seismic Moho depth data}

Moho depth data are sparsely available in the Gulf of Lion and surrounding areas. Continental refraction data indicate an average Moho depth of 30-32 km on the mainland (southern Rhône valley, Sapin and Hirn 1974; Spanish mainland, Zeyen et al. 1985; Danobeitia et al. 1992). Moho depth is increasing to $60-65 \mathrm{~km}$ beneath 
the Pyrénées belt (Choukroune et al. 1989, 1990; Anguy et al. 1991) and to 55-60 km beneath the Alps (Giese et al. 1973). Beneath the Balearic Islands the Moho lies at an average depth of $22 \mathrm{~km}(18 \mathrm{~km}$ under Menorca after Banda et al. 1980; 24 to $28 \mathrm{~km}$ under Mallorca after Danobeitia et al. 1992). The Moho is slightly deeper beneath Corsica and Sardinia (average $30 \mathrm{~km}$ depth, Egger, 1988, 1992).

At sea, both refraction and reflection data are available. Based on Expanding Spread Profiles (ESP) the average Moho depth in the Liguro-Provençal Basin and in the Valencia Trough is $15 \mathrm{~km}$ (Le Douaran et al. 1984; Gallart et al. 1990; Danobeitia et al. 1992; Mauffret et al. 1992; Pascal et al. 1992; Torné et al. 1992; Pascal et al. 1993; Mauffret et al. 1995). The Liguro-Provençal Basin is floored with thin oceanic crust of early Miocene age (Bayer et al. 1973; Burrus, 1984), whereas thin continental crust underlies the Valencia Trough (Watts and Torné 1922a, 1992b; Pascal et al. 1992). Progressive thinning of the continental crust from the upper margin to the deeper basin is clearly evidenced over the Gulf of Lion margin through subsidence analysis (Steckler and Watts 1980) and multichannel deep seismic profiling (ECORS profiles, de Voogd et al. 1991). The exact position of the ocean-continent boundary is however still debated (e.g. Pascal et al. 1993; Mauffret et al. 1995; review in Vially and Trémolières, 1996).

The non-uniform data distribution precludes the use of standard interpolation to recover a complete Moho depth map. We thus briefly describe in the following section the use of gravity data to better constrain the Moho depth map where no other information is available.

\subsection{D gravity inversion procedure}

The 3-D inversion procedure is based on Fourier Transform (FT) methods (Parker, 1973), using the first order theory in which high order terms in the gravity expansion are being neglected. The gravity anomaly at the earth's surface due to a periodic undulation $h(x, y)$ of an interface at depth $\mathrm{d}$ associated with a constant density contrast $\Delta \rho$ is thus given by:

$$
\Delta \mathrm{g}(\mathrm{x}, \mathrm{y})=2 \pi \mathrm{G} \Delta \rho \mathrm{h}(\mathrm{x}, \mathrm{y}) \mathrm{e}^{-\mathrm{kd}}
$$

where $\mathrm{k}$ is the wavenumber of the undulation ( $k=2 \pi / \lambda$, where $\lambda$ is the wavelength) and $G$ is the universal gravity constant. Fourier transforming this equation leads to:

$$
\Delta \mathrm{g}^{*}\left(\mathrm{k}_{\mathrm{x}}, \mathrm{k}_{\mathrm{y}}\right)=2 \pi \mathrm{G} \Delta \rho \mathrm{h} *\left(\mathrm{k}_{\mathrm{x}}, \mathrm{k}_{\mathrm{y}}\right) \mathrm{e}^{-\mathrm{kd}}
$$

where $\Delta \mathrm{g}^{*}\left(\mathrm{k}_{\mathrm{x}}, \mathrm{k}_{\mathrm{y}}\right)$ and $\mathrm{h} *\left(\mathrm{k}_{\mathrm{x}}, \mathrm{k}_{\mathrm{y}}\right)$ denote the 2D Fourier Transform of the gravity signal and of the undulations, respectively $\left(\mathrm{k}_{\mathrm{x}}\right.$ and $\mathrm{k}_{\mathrm{y}}$ are the horizontal wavenumbers in $\mathrm{x}$ and $\mathrm{y}$ directions). $\mathrm{h} *\left(\mathrm{k}_{\mathrm{x}}, \mathrm{k}_{\mathrm{y}}\right)$ can thus be obtained by Fourier transforming the gravity signal as:

$$
\mathrm{h}^{*}\left(\mathrm{k}_{\mathrm{x}}, \mathrm{k}_{\mathrm{y}}\right)=1 /(2 \pi \mathrm{G} \Delta \rho) \Delta \mathrm{g} *\left(\mathrm{k}_{\mathrm{x}}, \mathrm{k}_{\mathrm{y}}\right) \mathrm{e}^{\mathrm{kd}}
$$

Inverse FT finally leads to $\mathrm{h}(\mathrm{x}, \mathrm{y})$.

Exponential terms in (3) at high wavenumbers (short wavelengths) require filters to smooth the observed data prior to inversion. We tested a number of filters in the spectral domain by using forward and inverse modelling. Best results were obtained using gaussian or cosine filters to attenuate short wavelengths before applying the inverse FT. Such filters also minimises the side-lobe effects inherent to FT methods. A cosine filter cutting all wavelengths shorter than $60 \mathrm{~km}$ was used in the final solutions.

The method applies to a single interface with known reference level (d) and density contrast $(\Delta \rho)$. We show in the next section how we derived a mantle Bouguer gravity anomaly to perform the inversion on the Moho discontinuity, and how we adjusted the reference level and crust-mantle density contrast.

\subsection{Mantle Bouguer in the Liguro- Provençal Basin}

Bathymetry and topography were taken from the International Bathymetric Chart of the Mediterranean (IBCM) and from the ETOPO5 digital data files respectively. A single sedimentary layer from sea bottom to top of basement is used. The basement depth map was compiled from Arthaud et al. (1980) for the Oligocene sedimentary basins offshore, a digital data file from Mauffret (personal communication) and Gorini (1993) for the Gulf of Lion, Réhault (1981) for the Ligurian Sea and surrounding areas, Maillard et al. (1992) for the Valencia Trough, Moussat (1983) and Réhault et al. (1987) for the Tyrrhenian Sea, Réhault et al. (1984) for the remaining areas. Data were compiled in seismic two-way travel time. Velocities at ESP reprocessed by Pascal et al. (1993) were then used for time to depth conversions. 
Gravity maps were derived from the IBCM Bouguer anomaly maps. Since in the oceanic domain a simple Bouguer approximation with a density of $2670 \mathrm{~kg} / \mathrm{m}^{3}$ was used in the IBCM charts, we first recalculated the corresponding free-air anomaly with the bathymetry also provided by IBCM. The obtained free-air anomaly map (Fig. 1) was compared to two other sources of data: individual free-air gravity profiles extracted from the GEOMAR data base and satellite-derived gravity field of Sandwell (Sandwell and Smith, 1995). At wavelengths greater than $15 \mathrm{~km}$ the IBCM ship-derived map does not differ significantly from the satellite gravity map. The latter has however a much better resolution due to continuous cover as opposed to nonuniform ship track coverage.

The final mantle Bouguer anomaly map was obtained by correcting the free-air anomaly for water and sediment, both being replaced by crust (Fig. 2). This was done by calculating their respective gravity contribution using contouring and summing up individual thin (100 m thick) sheet contributions in 3D (Talwani and Ewing, 1960). Notice that at this stage, Fourier domain gravity expansion was not used. 3D marine Bouguer anomaly maps (replacing water by sediment) were also produced.

\subsection{Reference level and crust-mantle density contrast}

The mantle Bouguer gravity anomaly can be attributed to Moho undulations to a first approximation. The possible contribution of deeper sources, in particular the effect of laterally variable thermal and crustal density structure, will be discussed in a later section. If we consider topography of the Moho as the only gravitational source remaining, then the previous inversion methodology applies. Free parameters in the gravity inversion are the reference level (depth d) and the density contrast of the crust-mantle boundary $(\Delta \rho)$. Uncertainties, apart from the over simplified sedimentary column, arise from the choice of the mean sediment density and crustal density used to calculate the mantle Bouguer. The best couple of parameters $d$ and $\Delta \rho$ was determined by minimising by least squares fit the difference between the calculated Moho depth and the observed seismic Moho depth.

Results for $\mathrm{d}$ and $\Delta \rho$ best couple are displayed in Figure 3, and seismic Moho depth and gravimetric Moho depth are compared in Table 1. We tested the influence of sediment and crust density in the range $2200-2350 \mathrm{~kg} / \mathrm{m}^{3}$ and $2750-2800 \mathrm{~kg} / \mathrm{m}^{3}$ respectively. Quality of the fit is rather insensitive to densities, with a standard deviation of $2300 \mathrm{~m}$ for all runs at refraction and reflection control points (mean misfit between seismic and gravimetric Moho depths). Standard deviation for ESP points only (oceanic domain) reduces to $1500 \mathrm{~m}$ for the same runs. In all cases the best reference level was found close to $27-28 \mathrm{~km}$. Varying the sediment density or the crust density is merely accommodated by a modification of the $\Delta \rho$ contrast at the crust-mantle interface: $\Delta \rho$ is increasing with decreasing sediment density (Fig. 3d) and/or increasing crust density (Fig. 3c). A reasonable $\Delta \rho$ contrast of $580 \mathrm{~kg} / \mathrm{m}^{3}$ was obtained for a mean sediment density of $2350 \mathrm{~kg} / \mathrm{m}^{3}$ and a crustal density of $2750 \mathrm{~kg} / \mathrm{m}^{3}$, thus giving a mantle density of $3330 \mathrm{~kg} / \mathrm{m}^{3}$. This model is referred to as Model A in the following discussions (Fig. 4a).

Fourier domain expression for gravity requires the reference level to be the median depth of the interface in order to optimise convergence of the series expansion (Parker, 1973; Cowie and Karner, 1990). The same limitation applies for the first order theory used here (non zero first term only), so that the solution will only be approximate if the median depth of the interface is different from the reference level. The reference level found through the inversion process $(27-28 \mathrm{~km})$ is actually deeper than the a posteriori calculated mean depth of the interface $(25 \mathrm{~km})$. The corresponding error in the calculated gravity is a function of the wavelengths of the anomalies through the exponential term in Equation (1), the error decreasing with increasing wavelength. The validity of the final solution was checked by calculating the true 3D Bouguer (using the discrete sum of thin sheet contributions, Talwani and Ewing, 1960). The standard deviation of the residual (observed minus modelled, Fig. 5) is $15 \mathrm{mgal}$, or $600 \mathrm{~m}$ translated into depth of the Moho. Typical misfit reaches $20 \mathrm{mgal}$ on the margins and $10 \mathrm{mgal}$ in the deeper parts of the basin. The misfit is high towards the sides of the box due to the outside box apodisation prior to Fourier inversion. At that point, the obtained solution could easily be improved by re-introducing short wavelengths as small perturbations of the Moho. 


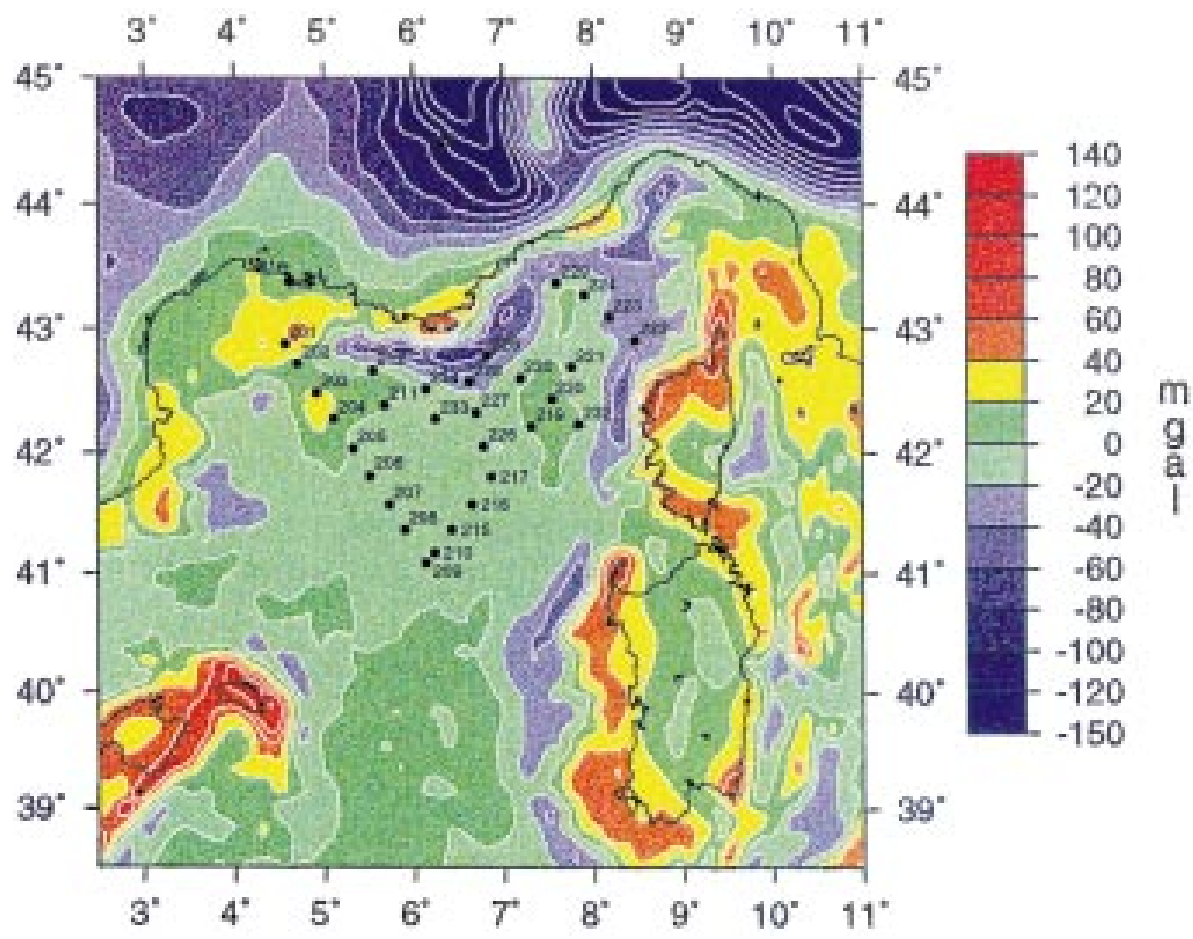

Figure 1

Free-air anomaly map in the Liguro-Provençal Basin. On land: Bouguer anomaly from the IBCM charts (Bouguer density 2.67). Contour interval: 20 mgal.

Figure 2

Mantle Bouguer anomaly map (Model A solution; no thermal correction nor variable crust density correction). Contour interval: $30 \mathrm{mgal}$.

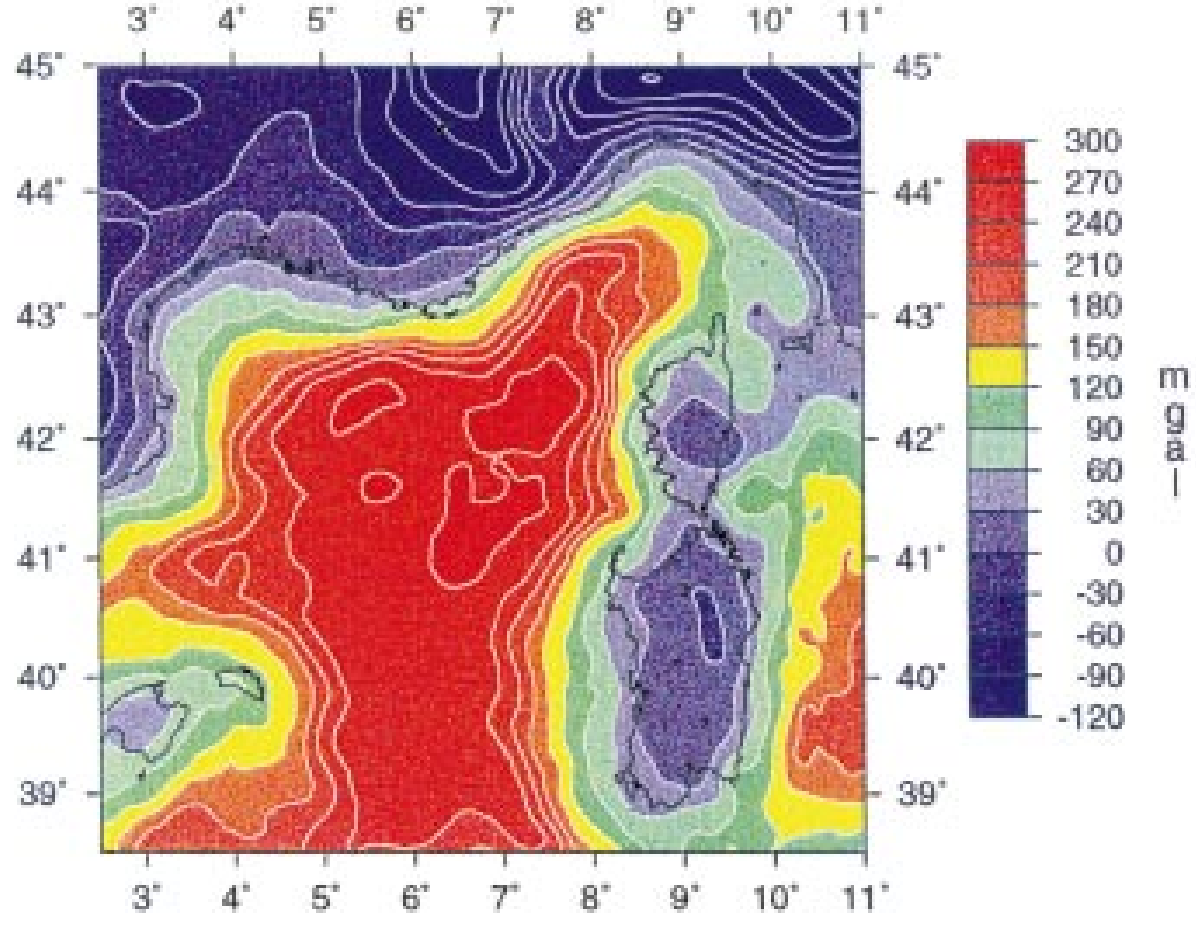

REVUE DE L'IN STITUT FRAN ÇAIS DU PÉTRO LE VO L. 52, N॰6, N O VEM BRE-DÉC EM BRE 1997 

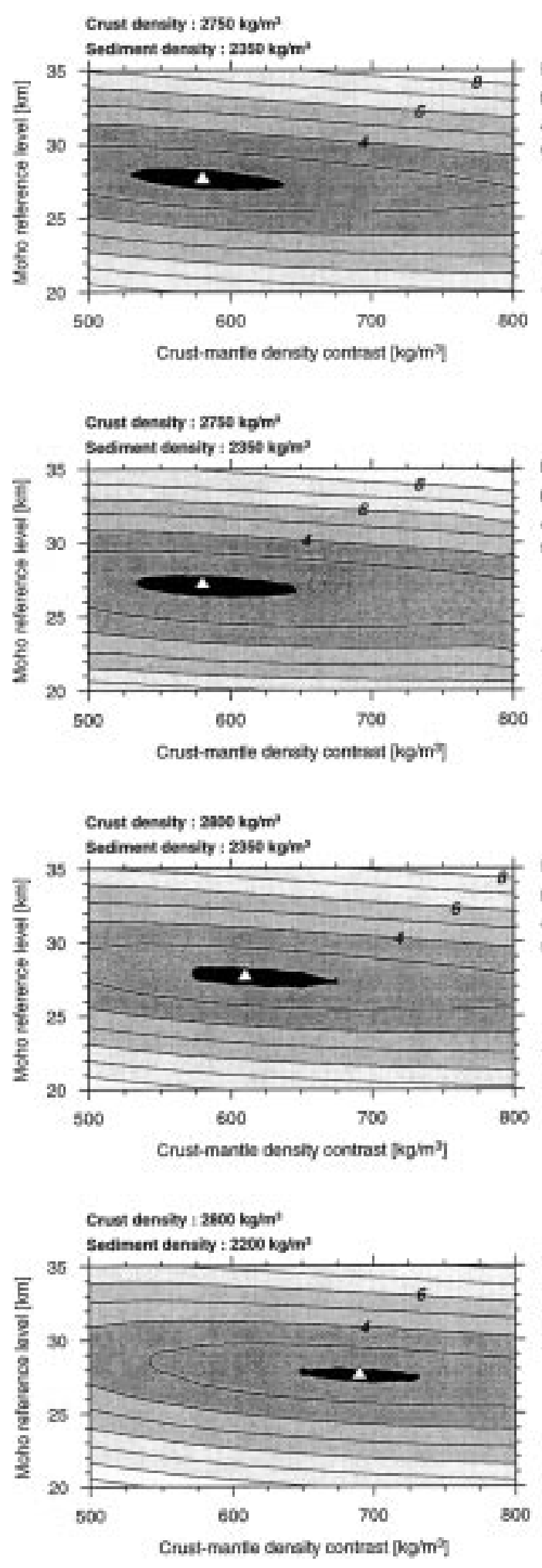

Aest 2 in incorations:

Moho selevence level : $27,7 \mathrm{~km}$

4p: $: 500 \mathrm{kgm}^{2}$

s.d : $: 2.31 \mathrm{~km}$

A

\section{MODEL A}

No thermal correction

\section{MODEL B}

\section{With thermal correction}

\section{Best fr ieformations !}

Maho salance leves: $27.7 \mathrm{~km}$

$4 p: 650 \mathrm{~kg}^{2}$

s.d : $2.31 \mathrm{~km}$

C

\section{Increased crust density \\ No thermal correction}

Best fit imbarmations :

Meha nelerinos itvel : $27.6 \mathrm{~km}$

ag : $680 \mathrm{kgm}$ "

s.d. $12.35 \mathrm{~km}$

D

\section{Decreased sediment density}

\section{No thermal correction}

Figure 3

Reference Moho depth (d) and mantle-crust density contrast $(\Delta \rho)$ best couple obtained by least squares minimisation at seismic control points (standard deviation s.d. in $\mathrm{km}$ ). A: MODEL A solution (no thermal nor variable crust density corrections; $\mathrm{d}=27.7 \mathrm{~km}$ and $\Delta \rho=580 \mathrm{~kg} / \mathrm{m}^{3}$ ). B: MODEL B solution (includes thermal and variable crust density corrections). C: effect of crust density increase. D: effect of sediment density decrease. 
TABLE 1

Comparison between seismic Moho depth and gravimetric Moho depth at ESP control points (for both Model A and Model B solutions). s.d. is standard deviation in $\mathrm{km}$.

\section{Results of the 3D gravity inversion at ESP points}

Model A: no thermal and no variable crust density corrections

Model B: thermal and variable crust density included

\begin{tabular}{|c|c|c|c|c|c|c|c|c|c|}
\hline$\left({ }^{\circ}\right)$ & (') & $\left({ }^{\circ}\right)$ & (') & $\begin{array}{c}\text { ESP } \\
n^{\circ}\end{array}$ & $\begin{array}{c}\text { Seismic Moho } \\
\text { km }\end{array}$ & $\begin{array}{l}\text { Model A } \\
\text { km }\end{array}$ & $\begin{array}{l}\text { Misfit } \\
\mathrm{km}\end{array}$ & $\begin{array}{c}\text { Model B } \\
\text { km }\end{array}$ & $\begin{array}{c}\text { Misfit } \\
\text { km }\end{array}$ \\
\hline 42 & 53 & 4 & 34 & ESP201 & 19.9 & 22.2 & -2.3 & 21.9 & -0.2 \\
\hline 42 & 43 & 4 & 43 & ESP202 & 19.8 & 20.2 & -0.4 & 20.1 & -0.3 \\
\hline 42 & 29 & 4 & 55 & ESP203 & 15.1 & 15.4 & -0.3 & 16.1 & -1.0 \\
\hline 42 & 16 & 5 & 7 & ESP204 & 14.8 & 13.0 & 1.8 & 14.2 & 0.5 \\
\hline 42 & 2 & 5 & 20 & ESP205 & 14.2 & 14.3 & -0.1 & 15.9 & -1.7 \\
\hline 41 & 49 & 5 & 31 & ESP206 & 15.1 & 14.9 & 0.2 & 16.5 & -1.4 \\
\hline 41 & 34 & 5 & 44 & ESP207 & 14.7 & 15.1 & -0.4 & 16.4 & -1.7 \\
\hline 41 & 22 & 5 & 54 & ESP208 & 15.5 & 15.9 & -0.4 & 17.1 & -1.6 \\
\hline 41 & 5 & 6 & 8 & ESP209 & 15.3 & 15.4 & -0.1 & 16.7 & -1.4 \\
\hline 41 & 10 & 6 & 14 & ESP210 & 15.0 & 15.2 & -0.2 & 16.1 & -1.1 \\
\hline 42 & 23 & 5 & 41 & ESP211 & 14.6 & 12.6 & 2.0 & 13.4 & 1.2 \\
\hline 42 & 40 & 5 & 33 & ESP212 & 13.3 & 15.4 & -2.1 & 16.2 & -2.9 \\
\hline 41 & 22 & 6 & 26 & ESP215 & 15.0 & 15.0 & 0.0 & 15.4 & -0.4 \\
\hline 41 & 34 & 6 & 39 & ESP216 & 15.3 & 15.1 & 0.2 & 15.1 & 0.1 \\
\hline 41 & 48 & 6 & 52 & ESP217 & 14.0 & 15.0 & -1.0 & 14.5 & -0.5 \\
\hline 42 & 13 & 7 & 19 & ESP219 & 13.0 & 13.1 & -0.1 & 11.5 & 1.5 \\
\hline 42 & 26 & 7 & 32 & ESP220 & 12.5 & 12.0 & 0.5 & 10.4 & 2.1 \\
\hline 42 & 41 & 7 & 46 & ESP221 & 13.0 & 13.1 & -0.1 & 11.9 & 1.1 \\
\hline 42 & 55 & 8 & 28 & ESP222 & 15.5 & 19.4 & -3.9 & 18.6 & -3.1 \\
\hline 43 & 6 & 8 & 11 & ESP223 & 14.0 & 16.0 & -2.0 & 15.5 & -1.5 \\
\hline 43 & 16 & 7 & 54 & ESP224 & 13.0 & 13.3 & -0.3 & 13.7 & -0.7 \\
\hline 42 & 47 & 6 & 49 & ESP225 & 22.0 & 19.6 & 2.4 & 19.1 & 2.9 \\
\hline 42 & 3 & 6 & 47 & ESP226 & 14.0 & 14.4 & -0.4 & 13.4 & 0.6 \\
\hline 42 & 19 & 6 & 42 & ESP227 & 14.5 & 14.3 & 0.2 & 13.2 & 1.3 \\
\hline 42 & 34 & 6 & 37 & ESP228 & 20.5 & 16.8 & 3.7 & 16.2 & 4.3 \\
\hline 43 & 22 & 7 & 35 & ESP229 & 15.5 & 15.1 & 0.4 & 16.0 & -0.5 \\
\hline 42 & 36 & 7 & 11 & ESP230 & 12.0 & 14.2 & -2.2 & 12.5 & -0.5 \\
\hline 42 & 14 & 7 & 50 & ESP232 & 13.0 & 13.1 & -0.1 & 12.5 & 0.5 \\
\hline 42 & 16 & 6 & 15 & ESP233 & 13.5 & 14.3 & -0.8 & 14.2 & -0.7 \\
\hline 42 & 31 & 6 & 8 & ESP234 & 13.0 & 14.5 & -1.5 & 14.8 & -1.8 \\
\hline 41 & 4 & 3 & 41 & ESP002 & 14.5 & 16.9 & -2.4 & 17.6 & -3.1 \\
\hline
\end{tabular}




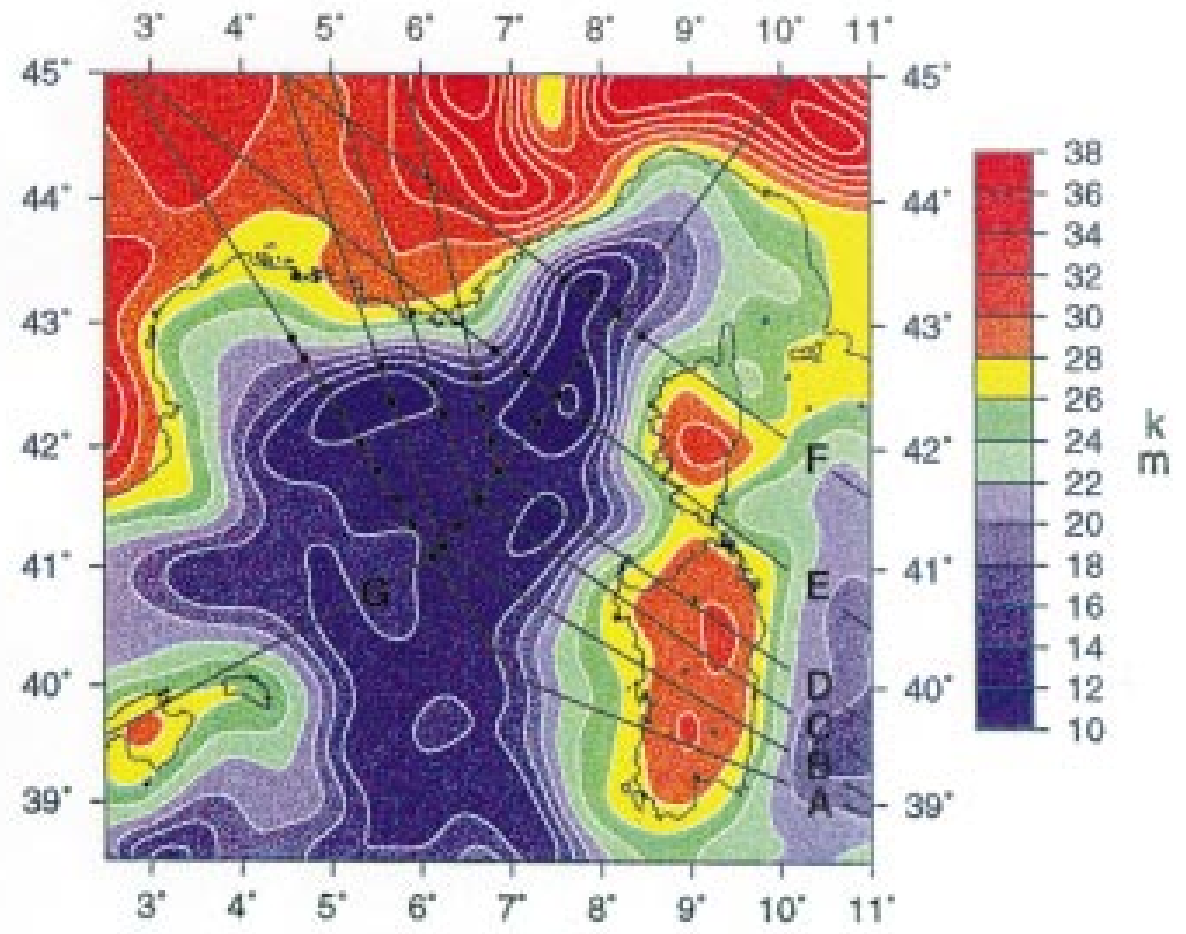

Figure 4a

Results of the 3D gravity inversion (depth to Moho contoured every $2 \mathrm{~km}$ ). Model A solution.

Figure 4b

Results of the 3D gravity inversion (depth to Moho contoured every $2 \mathrm{~km}$ ).

Model B solution. Location of seismic control points are shown as open dots. Sections A, B, C, $D, E, F$ and $G$ run across ESP data points at sea.

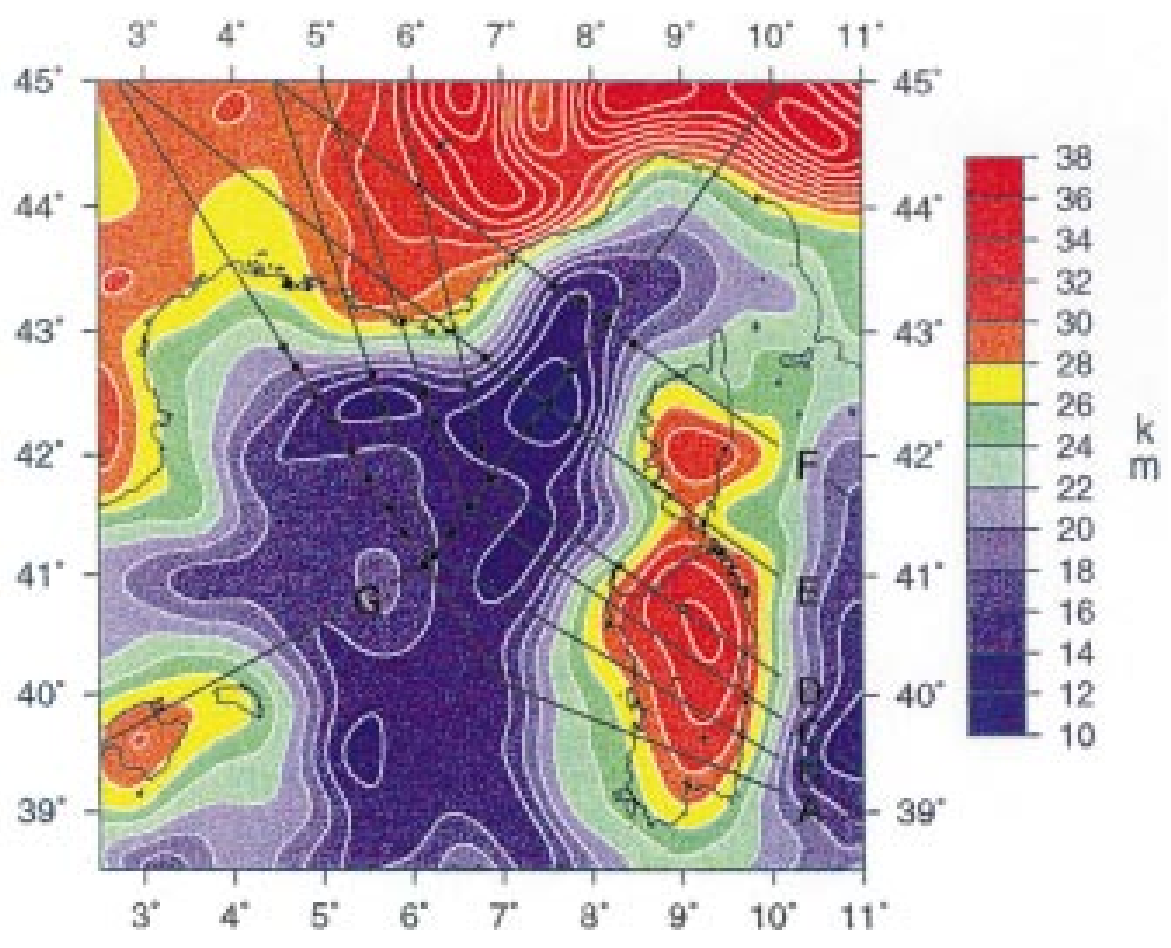

REVUE DE L'IN STITUT FRAN ÇAIS DU PÉTRO LE VOL. 52, $N^{\circ} 6$, N O VEM BRE-DÉC EM BRE 1997 


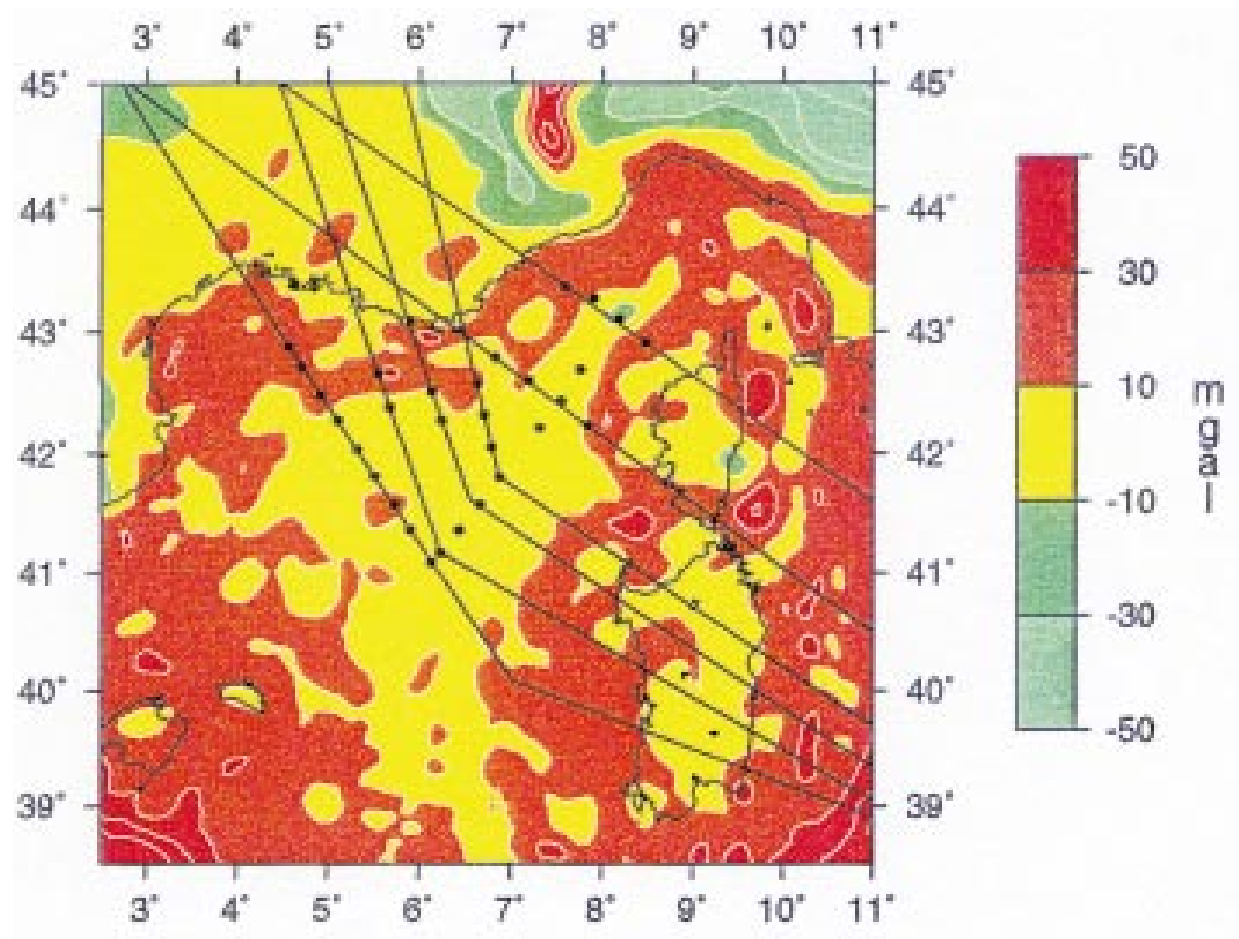

Figure 5

Residual Bouguer (observed minus modelled) using Model A solution and 3D analytic calculations (thin sheets summation).

\subsection{Thermal, variable crust density and variable sediment density corrections}

The observed heat flow in the Liguro-Provençal Basin is high (Fig. 6a). Values corrected for thermal blanketing are mostly above $100 \mathrm{~mW} / \mathrm{m}^{2}$ and reach $140-160 \mathrm{~mW} / \mathrm{m}^{2}$ in the axial part of the basin, based on the recent EGT heat flow compilation (European Geotraverse, Della Vedova et al., 1995). High heat flow anomaly in the basin is a consequence of the Oligocene rifting and the following short period of oceanic accretion. The net effect of the positive thermal anomaly in the basin is to reduce the mantle density at depth, producing a negative contribution of several tens of mgal to the gravity field (Watts and Torné, 1992).

To include this correction in the calculation of the mantle Bouguer, we modelled two sections across the basin: a Gulf of Lion section (section B located in Fig. 4) and a Ligurian section (section E located in Fig. 4). The temperature field was calculated following a pure shear Mc Kenzie type model for the rifting period (30 to $23 \mathrm{Ma}$ ), including lateral heat conduction and finite rifting duration (Alvarez et al., 1984), and oceanic accretion for the spreading period (23 to $19 \mathrm{Ma}$ ). Thermal cooling by conduction was assumed from $19 \mathrm{Ma}$ to present. Ages are taken from quantitative subsidence analysis of Bessis (1986) and Burrus (1989). The crustal structure used as input was derived from Model A solution. Finally, the thermal anomaly was converted to density anomaly to obtain the corresponding gravity field through $2 \mathrm{D}$ gravity modelling (Fig. 7).

The result of the $2 \mathrm{D}$ thermal/gravity modelling is that the anomalous gravity field can be directly obtained with a reasonable accuracy by simply multiplying in the Fourier domain the anomalous surface heat flow with an exponential function of Fourier gravity type (Fig. 7, top):

$$
\Delta \mathrm{g} *\left(\mathrm{k}_{\mathrm{x}}, \mathrm{k}_{\mathrm{y}}\right)=\mathrm{A} \Delta \phi^{*}\left(\mathrm{k}_{\mathrm{x}}, \mathrm{k}_{\mathrm{y}}\right) \mathrm{e}^{-\mathrm{kD}}
$$

where $\Delta \mathrm{g} *\left(\mathrm{k}_{\mathrm{x}}, \mathrm{k}_{\mathrm{y}}\right)$ is the gravity anomaly associated with the anomalous heat flow $\Delta \phi^{*}\left(\mathrm{k}_{\mathrm{x}}, \mathrm{k}_{\mathrm{y}}\right)$, and $\mathrm{A}$ and $\mathrm{D}$ are function parameters. Notice that $\mathrm{D}$ has the dimension of a distance and can be viewed as the mean depth of the thermal disturbance. A and $\mathrm{k}$ parameters integrate the geometry and amplitude of the thermal anomaly. Parameters A and D were found to be quite similar for the two sections modelled ( $\mathrm{A}$ in the range 2.95-3.04 $10^{-2} \mathrm{~m}^{3} \mathrm{~s}^{-2} \mathrm{~W}^{-1}$ and $\left.\mathrm{D}=50 \pm 3 \mathrm{~km}\right)$. Mean $\mathrm{A}$ and $\mathrm{D}$ values were thus applied to the thermal anomaly heat flow map to get a 3D estimate of the gravity 


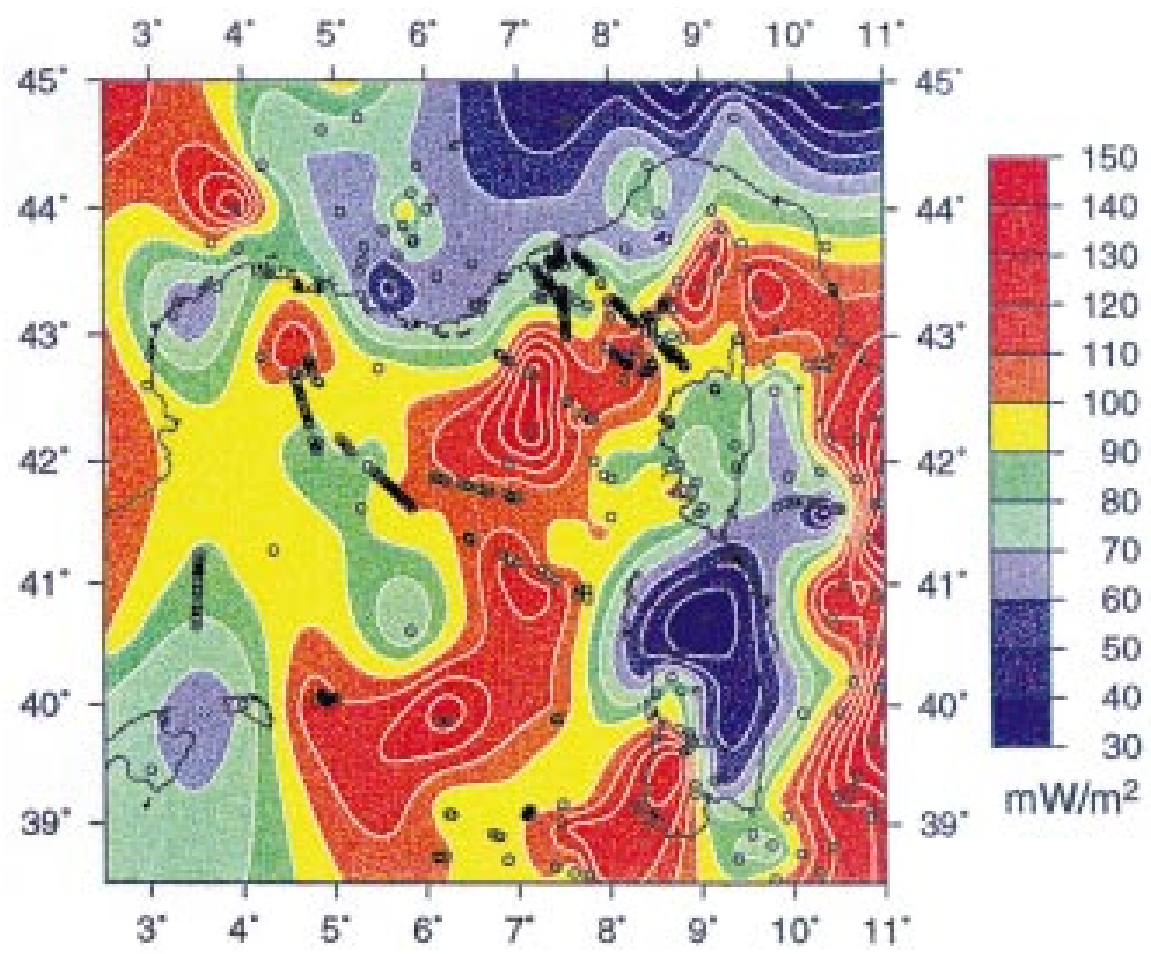

Figure 6a

Observed heat flow (open dots: data points, from Della Vedova et al. 1995). Contour interval: $10 \mathrm{~mW} / \mathrm{m}^{2}$.

\section{Figure $6 \mathrm{~b}$}

Calculated gravity effect of the decreasing mantle density with increasing surface heat flow. See text for details of the calculations. Contour interval: $10 \mathrm{mgal}$.

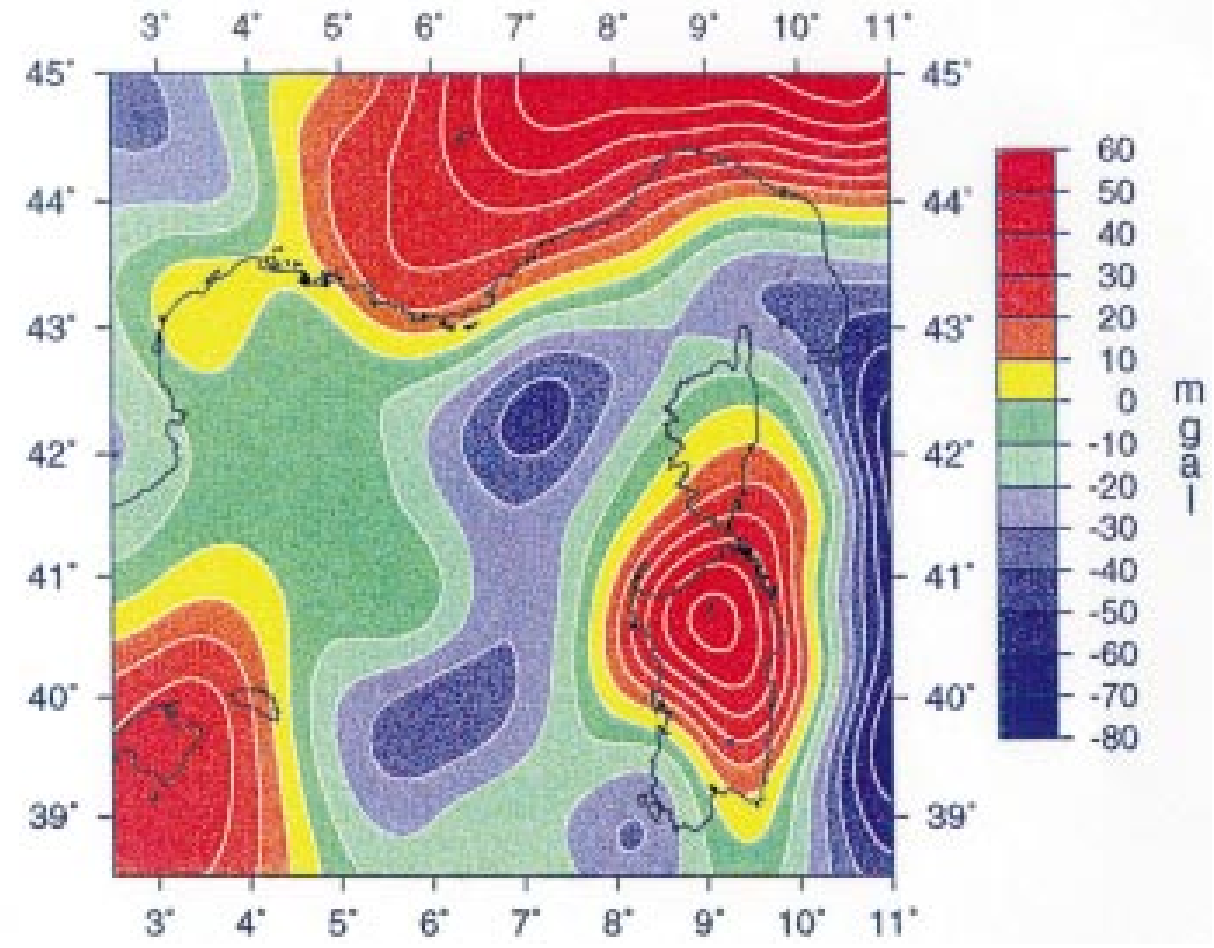

REVUE DE L'IN STITUT FRAN ÇAIS DU PÉTRO LE VO L. 52, N $6, N$ O VEM BRE-DÉC EM BRE 1997 
Left: 2D thermal modelling along a Gulf of Lion section (section B located in Fig. 4).

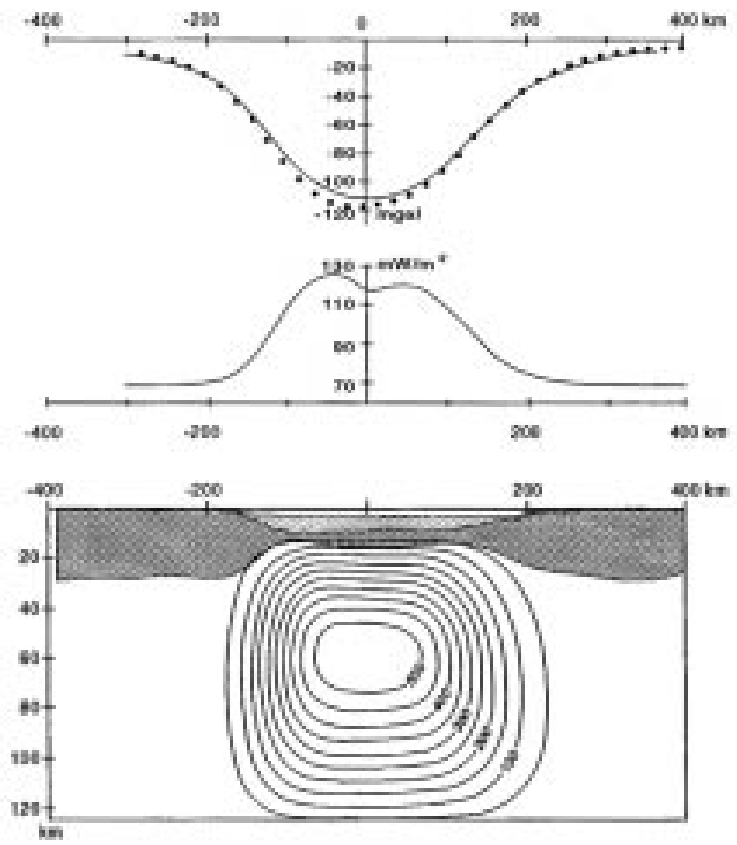

Right: 2D thermal modelling along a Ligurian Sea section (section E located in Fig. 4).

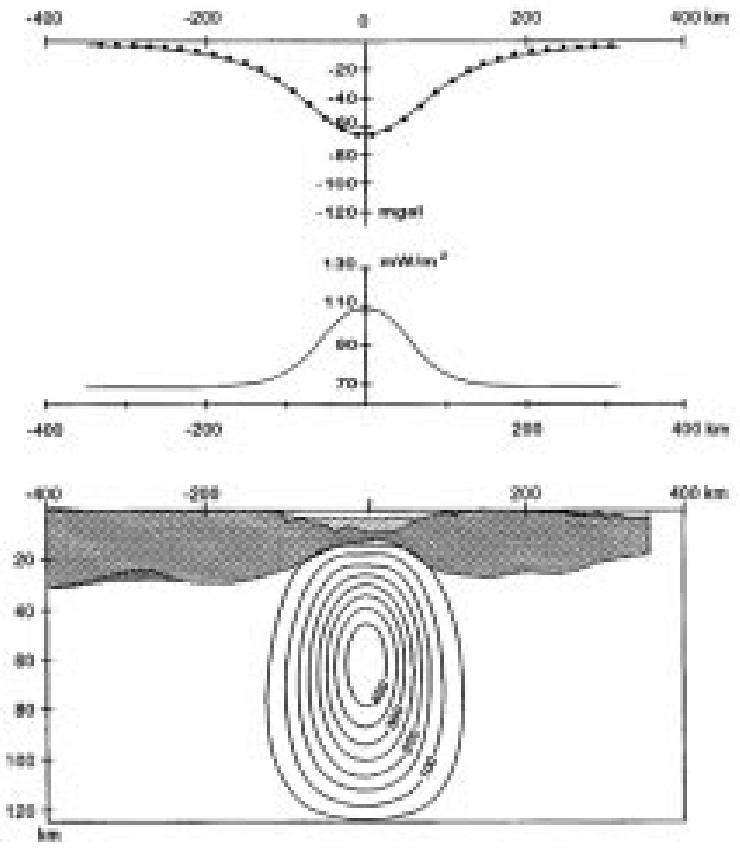

Figure 7

Bottom: Remaining present-day temperature anomaly following Oligo-Miocene rifting and oceanic accretion. Pure shear extension model is assumed. Contour interval: $50^{\circ} \mathrm{C}$.

Middle: Computed surface heat flow.

Top: Continuous curve: gravity signal induced by the thermal anomaly, calculated analytically using polygonal bodies. Dotted points: gravity signal directly calculated from the surface heat flow by means of Fourier transforming (see text for the details of the calculations).

contribution. The results are shown in Figure $6 b$. The negative thermal contribution to the gravity field is maximum in the axial part of the Liguro-Provençal Basin, towards the Ligurian Sea, where the gravity effect is reaching $-50 \mathrm{mgal}$. This is significantly less than the gravity effect calculated in 2D (-65 mgal and - 110 mgal for section B and E respectively) indicating that $2 \mathrm{D}$ modelling would overestimate the thermal correction. Notice that highest heat flow values were measured in the Ligurian Sea rather than the central part of the basin as would be predicted. We attribute the low values of the central part of the basin to the blanketing effect of the Rhône delta deposits.

A second type of correction is related to the lateral variations of the density of the crust. The density of the oceanic crust is known to be greater than the mean density of the continental crust. The contribution to the gravity field is opposite to the previous thermal correction since it implies a positive gravity anomaly over the oceanic domain. An estimation of this contribution was obtained by calculating the difference between a mantle Bouguer at $2750 \mathrm{~kg} / \mathrm{m}^{3}$ for crustal density and a mantle Bouguer at $2880 \mathrm{~kg} / \mathrm{m}^{3}$. The net gravity effect is reaching $+40 \mathrm{mgal}$ in the true oceanic domain. A similar estimate is reached if a simple Bouguer plateau approximation is calculated for a $7 \mathrm{~km}$ thick oceanic crust and a $130(2880-2750) \mathrm{kg} / \mathrm{m}^{3}$ oceanic crust-continental crust density contrast.

A last type of correction deals with the gravity effect of sediment compaction. If the density is increasing with depth, which is likely to be the case in a sedimentary basin, then the uniform density model 
tends to overestimate sediment density on the margins and correlatively underestimate density towards the centre of the basin. The amplitude of the gravity effect depends on the density-depth function and hence on lithologies. It reaches +50 mgal in the Viking Graben (North Sea) according to Cowie and Karner, (1990). Exponential type porosity-depth function down to about $4000 \mathrm{~m}$ below sea-floor are available for the Gulf of Lion margin from few industrial wells (Bessis, 1986). However, compaction will not follow a simple exponential density-depth variation in the deeper part of the basin due to the thick accumulation of salt and evaporites during the Messinian. Velocity-depth functions derived from expanding spread profiles indicate high $\mathrm{P}$-wave velocity (5.1 to $5.3 \mathrm{~km} / \mathrm{s}$ ) in the sediments lying immediately above the acoustic basement (Pascal et al., 1993). In the absence of any other information, empirical velocity-density conversion would give a $2550 \mathrm{~kg} / \mathrm{m}^{3}$ density for the lowermost sediments (Nafe and Drake, 1963). Using these constraints, the mean density would range from $2090 \mathrm{~kg} / \mathrm{m}^{3}$, estimated at ESP 225 where sediments are the thinnest $(1900 \mathrm{~m})$ to $2370 \mathrm{~kg} / \mathrm{m}^{3}$, estimated at ESP 204 where sediments are the thickest $(8000 \mathrm{~m})$. The net gravity effect, using a simple Bouguer plateau approximation, would reach $+30 \mathrm{mgal}$, equivalent to about $1 \mathrm{~km}$ of Moho topography. These estimations remain however highly speculative in the absence of reliable depth-density data, and we did not introduce this correction further.

Corrections for thermal and oceanic crust density were applied to derive a new Moho depth map, referred as model B (Fig. 4b). Notice that since the correction for thermal anomaly and the correction for variable crustal density are opposite in sign in the oceanic domain, model A and model B are quite similar there. On the mainland, negative heat flow anomaly (cold areas), such as beneath the Alps or beneath Sardinia, will tend to deepen the Moho in the gravity inversion. However, the way the gravity anomaly was derived from the heat flow is strictly valid in the oceanic domain only since homogeneous stretching followed by oceanic accretion was assumed. The quality of the fit at Moho control points is slightly enhanced in model B with respect to model A (standard deviation of $2000 \mathrm{~m}$ instead of $2300 \mathrm{~m}$ ). However, model B solution degrades at ESP control points $(1700 \mathrm{~m}$ versus $1500 \mathrm{~m}$ ). In particular, the calculated Moho in model B shows a systematic misfit along the ECORS profile
(Table 1). This misfit is mainly resulting from the low heat-flow values, relative to surroundings, that prevail over the Gulf of Lion area.

The conclusion is that model A (uncorrected) and model B (corrected for variable heat-flow and variable crust density) give quite similar results. In the next section, model A only will be considered since this solution is closer to ESP control points in the oceanic domain. We display in Figure 8 a set of crustal sections crossing the Liguro-Provençal Basin and Ligurian Sea through the refraction and reflection data points (sections are located in Fig. 4). Sections A to F are roughly perpendicular to the main structures. Section $G$ runs obliquely from Mallorca to the Ligurian Sea and the Gulf of Genoe. Mesozoic rifting in southern France was not included in the calculations, so that the gravimetric Moho is several kilometres deeper than the seismic Moho in the Rhône graben (section E). Apart from this discrepancy, and if we allow a standard error of $1 \mathrm{~km}$ on the seismically determined Moho (Pascal et al., 1993), the gravimetric solution fits the seismic data well.

\section{DISCUSSION}

\subsection{Variability of the oceanic crust thickness}

The mean oceanic crustal thickness is close to $5.0 \mathrm{~km}$. Systematic variability is however found both along strike (parallel to the magnetic lineations) and across (oceanic crust close to ocean-continent boundary). The southernmost part of the Ligurian Sea (section E in Fig. 8) is floored with very thin oceanic crust (Pascal et al., 1993; Mauffret et al., 1995). At ESP 220, the Moho is rising to less than $12 \mathrm{~km}$ depth, which is the shallowest point of the studied area. The mean crustal thickness is $3.3 \mathrm{~km}$ (ESP 219, 220, 221, 230, 232) which is significantly less than the average $5.0 \mathrm{~km}$ thickness.

Line G (Figure 8, bottom; located in Figure 4) is a cross-section running SW-NE in the deep basin from the island of Mallorca to the Gulf of Genoe. This alongstrike section follows more or less the axial LiguroProvençal Basin along the expected location of the fossil oceanic ridge, except for the northern end of the section. Notice the close agreement between the seismically determined Moho and model A gravimetric 


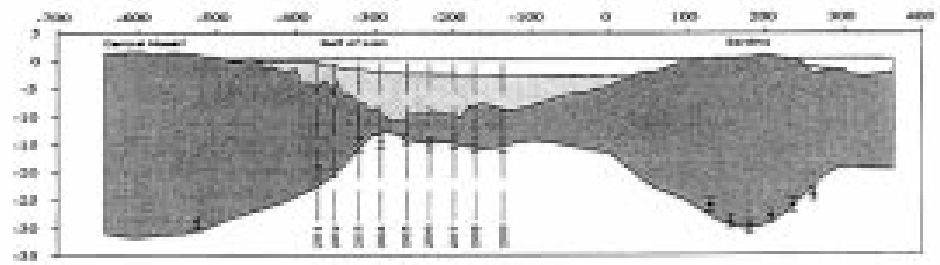

B

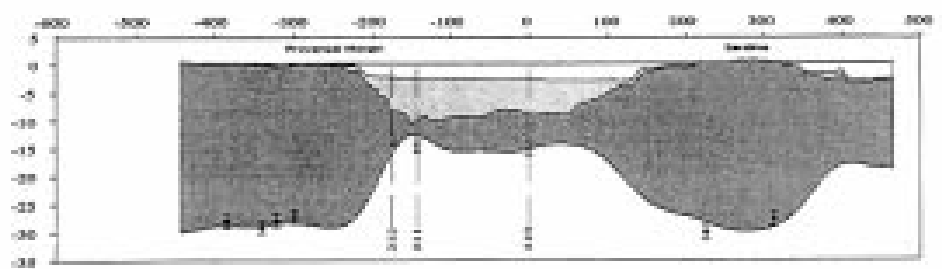

C

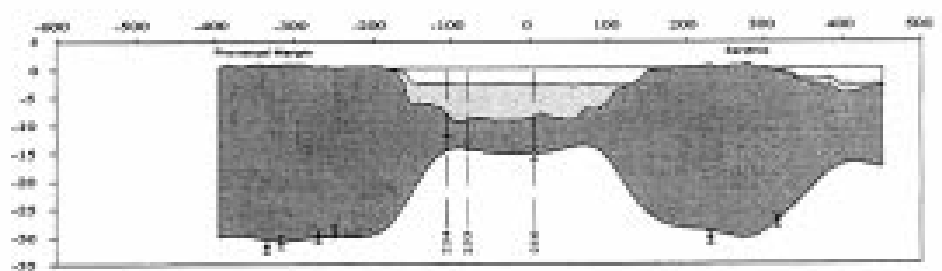

D

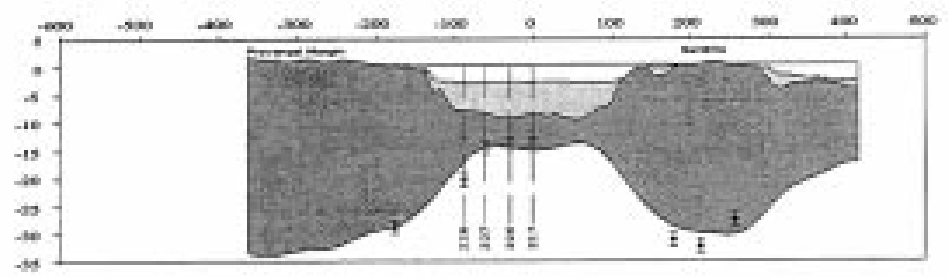

E

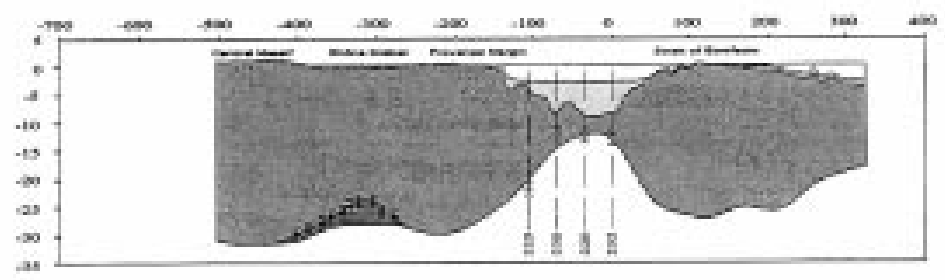

F
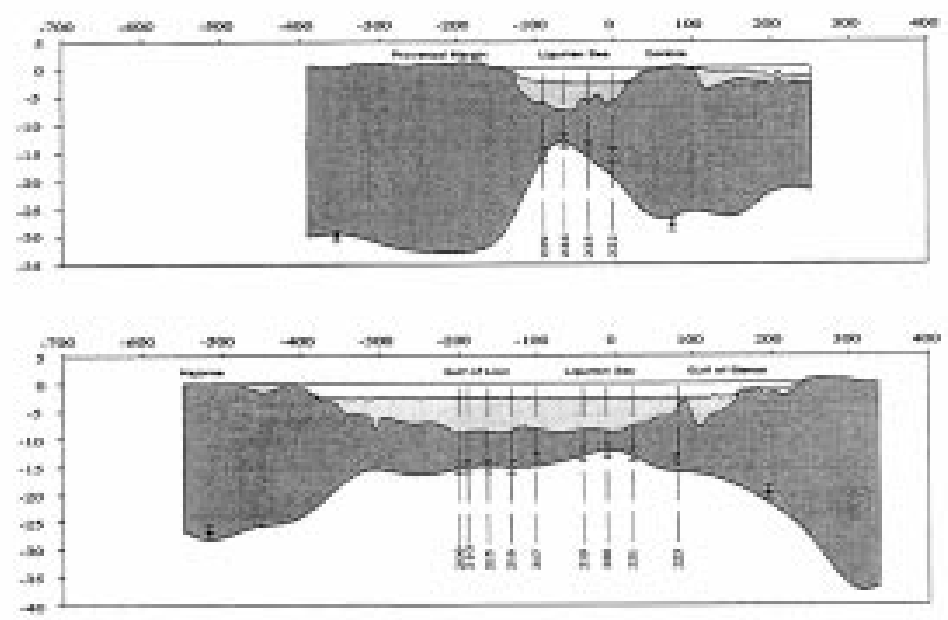

\section{Figure 8}

Crustal sections across the LiguroProvençal Basin deduced from 3D gravity inversion (Model A solution). Open dots: ESP data points at sea (vertical bar is $\pm 1 \mathrm{~km}$ ). Filled dots: reflection or refraction data points on land. Sections A to $\mathrm{G}$ are located in Fig. 4. 
solution. Oceanic crustal thickness along the section shows a remarkable gradual decrease towards the Ligurian Sea. At ESP 210 (along the ECORS line) crustal thickness is close to $5.5 \mathrm{~km}$, whereas it may be as thin as $2 \mathrm{~km}$ in the southernmost part of the Ligurian Sea (ESP 220).

Following pioneering works (Reid and Jackson 1981; Foucher et al., 1982), considerable progress has been made in the recent years on the calculations of volume of melt generated either during rifting (Mc Kenzie and Bickle, 1988; White and Mc Kenzie, 1989; Bown and White, 1995a, 1995b) or during oceanic spreading (Scott and Stevenson, 1989; White et al. 1992; Cordery and Morgan, 1993; Bown and White, 1994; Su et al., 1994). Production of oceanic crust is a result of partial melting of the mantle as it rises beneath spreading centres. The thickness of oceanic crust is thus directly related to the amount of partial melting, in turn controlled by asthenospheric mantle temperature and lithospheric temperature field. Under moderate to normal mantle temperature conditions (range of mantle temperatures producing less than 7-8 $\mathrm{km}$ thick crust), all models predict a decrease of crustal thickness with decreasing spreading rate and/or decreasing asthenospheric mantle temperature (Reid and Jackson, 1981; Bown and White, 1994; Su et al., 1994).

To explore further crustal thickness variation as a function of position in the basin, we use for each ESP the distance to the inferred Sardinia-Corsica pole of rotation (Fig. 10a and 10b). Different solutions have been proposed for the kinematics of the rotation (see review in Vially and Trémolières, 1996). They range from simple rotation about a single pole for both rifting and spreading to more complicated solutions involving several phases. In the following we use a commonly adopted solution with a pole of rotation located in the Gulf of Genoa (N 43.5०-E 9.0; Réhault et al., 1984). ESP data are located at distances to the pole ranging from $70 \mathrm{~km}$ (northermost Ligurian Sea section) to $350 \mathrm{~km}$ (Gulf of Lion, ECORS section).

We show in Figure 10a the predicted oceanic crust thickness for various potential asthenospheric mantle temperature (Bown and White, 1994). Crustal thickness is given as a function of distance to the pole. We assume a $9.8^{\circ} / \mathrm{Ma}$ rotation rate which matches the magnetic anomalies interpretation of Burrus (1984). Equivalent half-spreading rates are $30 \mathrm{~mm} / \mathrm{a}$ at a distance of $350 \mathrm{~km}$ and $6 \mathrm{~mm} / \mathrm{a}$ at a distance of $70 \mathrm{~km}$. Notice that since the pole rotation is relatively close, spreading rate is directly proportional to the distance to the pole. A first order interpretation of Figure 10a is that all oceanic data points fall close to, or below, the predicted curve for a $1280^{\circ} \mathrm{C}$ potential temperature. This is about $30^{\circ} \mathrm{C}$ to $50^{\circ} \mathrm{C}$ below normal temperature inferred at spreading centres away from hot spots and fracture zones (White et al., 1992; Bown and White, 1994).

The same conclusion was reached independently from a 3D analysis of the subsidence in the LiguroProvençal Basin (Chamot-Rooke et al., in preparation). After corrections for sedimentary loading, for abnormal crustal thickness and for potential effects of the recent compression regime, subsidence is still about $500 \mathrm{~m}$ greater than expected from the age of the basin. A low potential mantle temperature would thus explain both the abnormal subsidence of the deep basin and the low magma supply during oceanic accretion, leading to the production of abnormally thin oceanic crust. Similar low temperature boundary conditions may have also prevailed in the Tyrrhenian Basin (Réhault et al., 1990). This is not surprising since both the Liguro-Provençal Basin and the Tyrrhenian Basin opened as back-arc basins above the same lithospheric slab now subducting off Calabria (Le Pichon, 1984; Malinverno and Ryan, 1986). Thin crust and high subsidence have been reported in other marginal basins, in particular in the West Pacific. Low asthenospheric temperature may be the result of a long history of subduction of cold material, such as below the back-arc basins of the Philippine Sea plate for instance. In the Western Mediterranean, the amount of cold material subducted was probably much smaller, due to the slow convergence of Africa towards Europe. Lithospheric thickening coeval with orogenic compression may also be an efficient way to lower temperatures at mantle depth, provided time span between compression and extension is short enough to prevent thermal equilibration. Extensional collapse of a former orogen is now well established for the origin of the Tyrrhenian Basin (Kastens, Mascle et al., 1990; Jolivet et al., 1994). The potential role of the Pyrenean orogeny has also been discussed for the formation of LiguroProvençal Basin (Mauffret et al., 1995), although the continuity of the Pyrenean belt towards the Gulf of Lion margin has not been clearly established so far.

A closer examination to Figure 10a also shows the systematic trend observed along section G: oceanic crust becomes thinner closer to the pole of rotation, as 


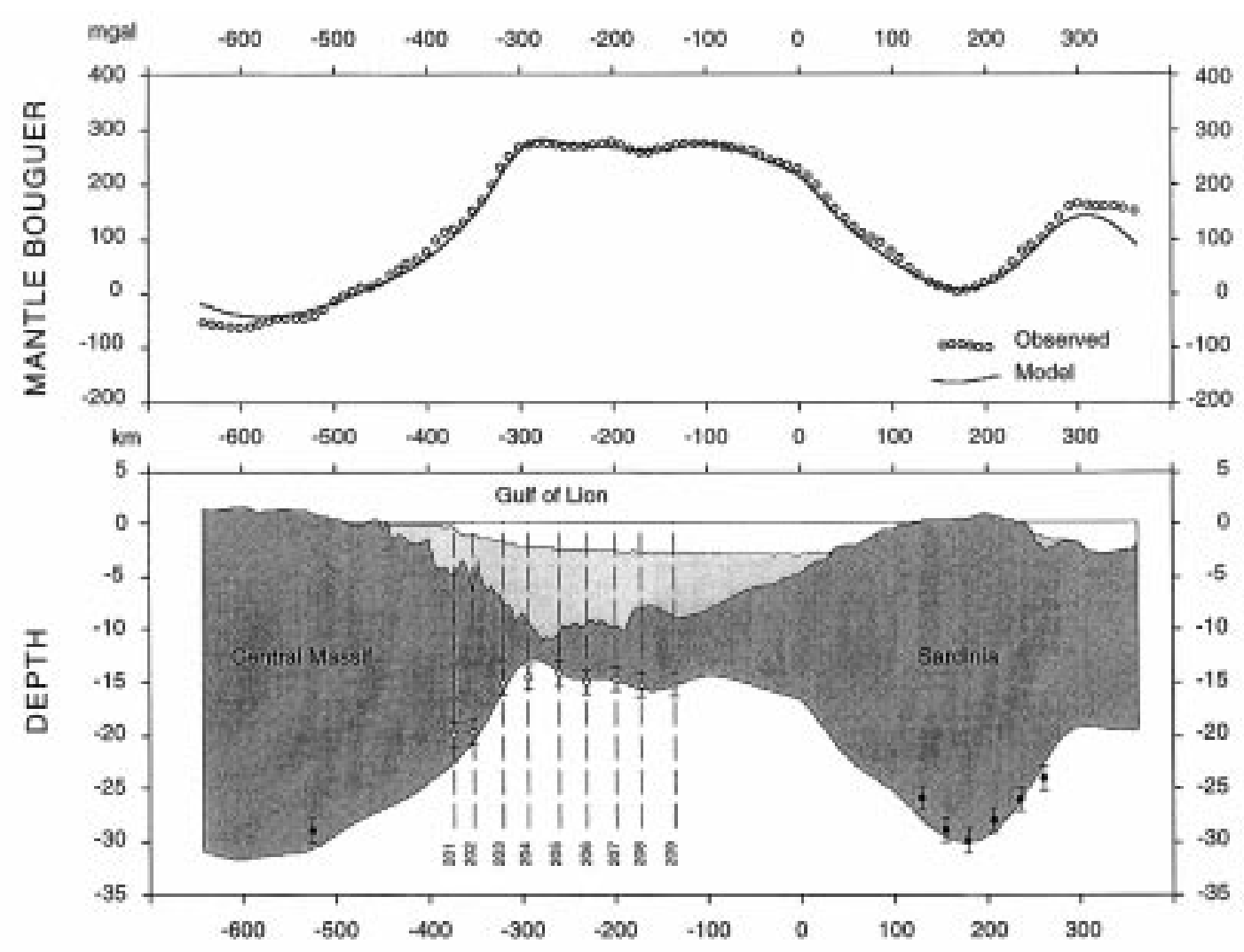

Figure 9

Crustal section obtained from 3D gravity inversion (Model A solution) along the ECORS profile (section A located in Fig. 4; Fig. 8 top). Top: observed and modelled Bouguer.

predicted by melting models through spreading rate dependence. According to Bown and White (1994) models, a sharp decrease in melt production occurs at full spreading rates below $15 \mathrm{~mm} / \mathrm{a}$, whereas at higher rates the oceanic crust thickness is remarkably uniform (7 $\pm 1 \mathrm{~km}$ average, after White et al., 1992). Small oceanic crust thickness is well documented at the slow spreading Arctic ridge, where the crust is about $2.5 \mathrm{~km}$ thick for a 12 to $15 \mathrm{~mm} / \mathrm{a}$ full rate (Jackson et al., 1982), and close to some of the Atlantic non-volcanic margins (review in Bown and White, 1994; Srivastava and Roest, 1995). In the Liguro-Provençal Basin, a marked decrease in oceanic crust thickness occurs in the southernmost part of the Ligurian Sea, or $200 \mathrm{~km}$ away from the pole of rotation (Fig. 10a and 10b). The predicted full spreading rate there would be $34 \mathrm{~mm} / \mathrm{a}$, assuming a $9.8^{\circ} / \mathrm{Ma}$ rotation rate. This is more than twice the trade-off value of $15 \mathrm{~mm} / \mathrm{a}$ inferred from modelling and observations.
The thin crust of the Ligurian Sea may result from two effects:

- heat was lost laterally towards the adjacent continents (Provençal margin and Corsica), thus preventing large-scale melting even during oceanic accretion;

- rate of opening was half the value generally assumed, and consequently the critical $15 \mathrm{~mm} / \mathrm{a}$ full spreading rate below which magma supply is small was reached at a distance of $200 \mathrm{~km}$ from the pole.

The latter hypothesis is explored in Figure 10b where we show the predicted oceanic crust thickness for different opening rates. A good solution is obtained if the opening rate is close to $5^{\circ} / \mathrm{Ma}$.

Lateral heat conclusion can be effective both during continental rifting and early oceanic spreading. During rifting, heat transfer from hot extended area to cooler surroundings reduces significantly the amount of melt generated, so that even at potential temperature above normal, little or no melt is produced (Alvarez 


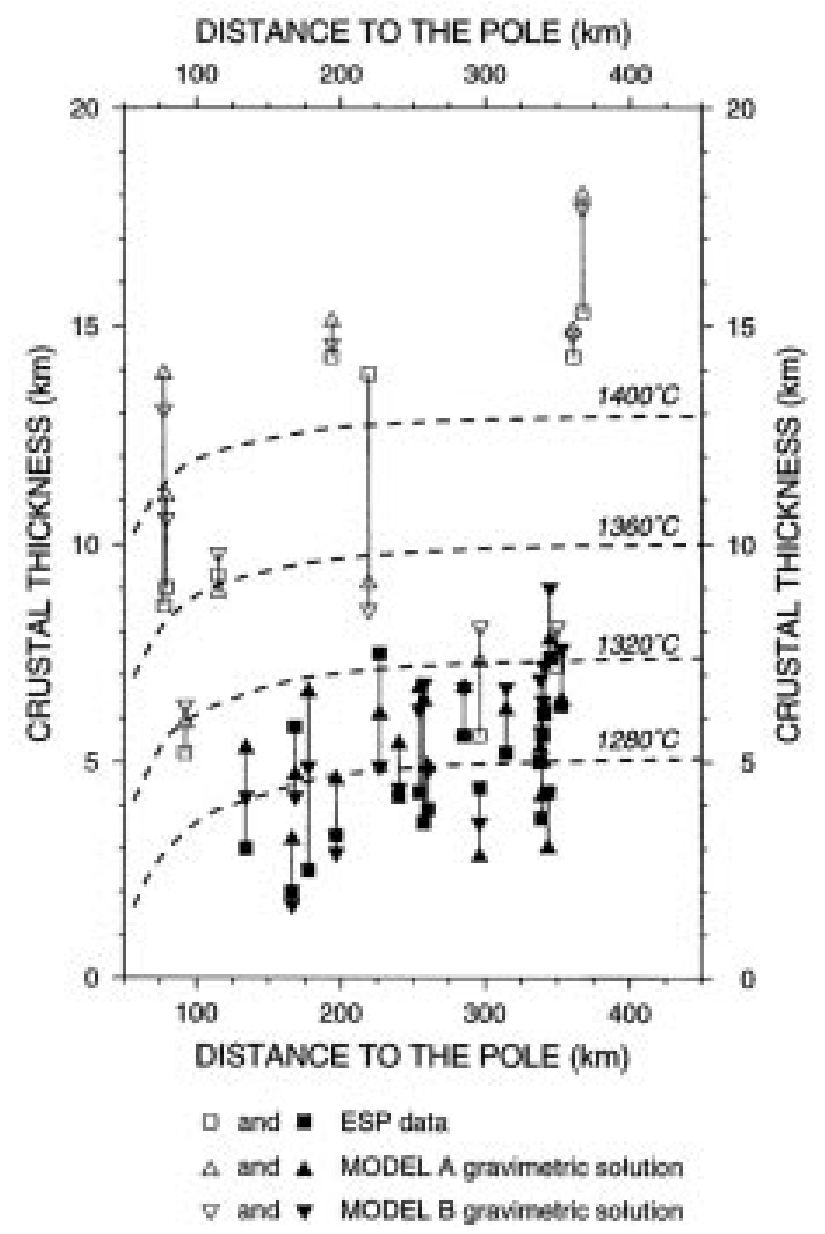

Figure 10a

Crustal thickness (MODEL A, MODEL B and seismic refraction) at ESP points versus distance to the pole of opening. Dashed curves: predicted oceanic crustal thickness for various potential mantle temperature $\left(1280^{\circ} \mathrm{C}\right.$ to $1400^{\circ} \mathrm{C}$, from Bown and White, 1994). $30 \mathrm{~mm} / \mathrm{a}$ half-spreading rate is assumed along the ECORS line ( $350 \mathrm{~km}$ away from the pole; spreading rate derived from Burrus, 1984). Equivalent rotation rate is $9.8^{\circ} / \mathrm{Ma}$. Filled symbols: oceanic or transitional type crust. Open symbols: continental crust.

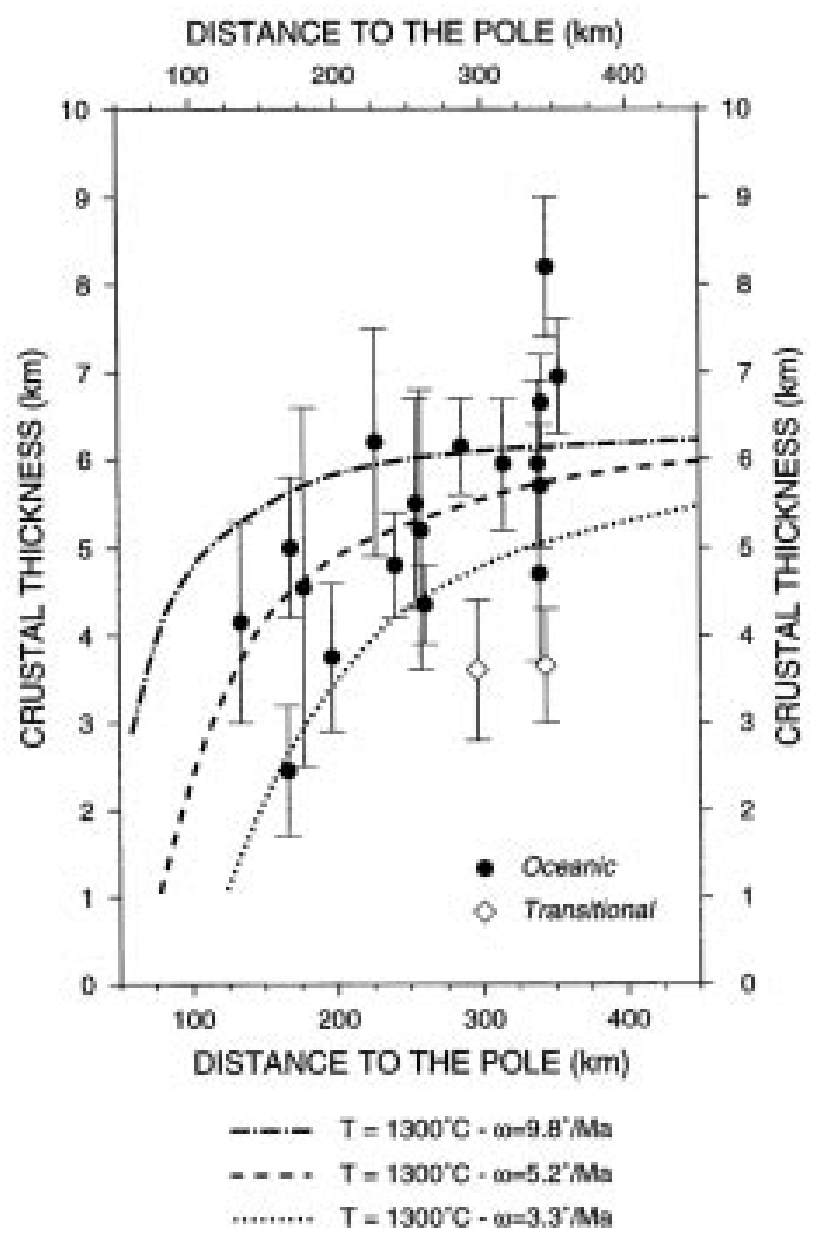

Figure 10b

Range of crustal thickness for oceanic crust (filled circles) and transitional type crust (open diamonds) versus distance to the pole of opening. Dashed curves are model predictions using the same mantle temperature $\left(1300^{\circ} \mathrm{C}\right)$ but different rotation rates: $9.8^{\circ} / \mathrm{Ma}, 5.2^{\circ} / \mathrm{Ma}$ and $3.3^{\circ} / \mathrm{Ma}$, equivalent to $30 \mathrm{~mm} / \mathrm{a}, 20 \mathrm{~mm} / \mathrm{a}$ and $10 \mathrm{~mm} / \mathrm{a}$ half-spreading rates along the ECORS line (section A, Fig. 4) and to $15 \mathrm{~mm} / \mathrm{a}, 8 \mathrm{~mm} / \mathrm{a}$ and $5 \mathrm{~mm} / \mathrm{a}$ half-spreading rates in the Ligurian Sea (section E, Fig. 4). et al., 1984). This effect, combined with finite-as opposed to instantaneous-duration of rifting, explains the absence of significant amount of melt produced at non-volcanic continental margins (Bown and White, 1995a, 1995b). Lateral heat loss can also be efficient in reducing crustal thickness during the early phase of oceanic spreading. The time to establish a permanent thermal regime at the ridge axis is highly dependent on the spreading rate. At high spreading rate, the ridge will rapidly leave away from the cooler adjacent continent.
On the contrary, small transient perturbations at slow spreading ridges will have large effects on the thickness of oceanic crust produced (Su et al., 1994). At high potential temperatures, the relative importance of buoyancy-driven mantle flow with respect to platedriven mantle flow may even lead to an increase in crustal thickness with decreasing spreading rates (Su et al., 1994). However, at low to normal potential temperatures as those considered here, plate-driven flow will dominate and variations in crustal thickness 
will basically reflect variations in the temperature field. How far the ridge temperature field is affected by the proximity of the continent depends not only on the oceanic spreading rate but also on the kinematics of stretching. For short rifting duration and high thinning factor, reducing the continental crust to oceanic crust thickness, the stretched continental crust is thermally indistinguishable from oceanic crust. More generally, the duration of rifting and the amount and distribution of thinning, as well as spreading rate, will control the temperature field and thus oceanic crust genesis at the ocean-continent boundary.

A convenient way to estimate the time needed to establish a steady-state thermal regime at the ridge axis is to follow the abnormal subsidence induced by lateral conduction towards cooler continent. Section E, located in Figure 4, crosses the area of abnormally thin oceanic crust at the southernmost end of the Ligurian Sea. A thermal model including continental rifting (from 30 to $23 \mathrm{Ma}$ ), oceanic spreading (from 23 to $19 \mathrm{Ma}$ ) and post spreading cooling (from 19 Ma to present) was already presented and discussed in a previous section (Fig. 7). We are interested now in the very early phase of oceanic spreading. The rifting history and amount of stretching is taken identical to the model of Figure 7. The steady-state solutions (including lateral conduction) for intermediate $(40 \mathrm{~mm} / \mathrm{a})$ and slow $(18.5 \mathrm{~mm} / \mathrm{a})$ spreading are shown as large dots in Figure 11. This is equivalent to the ocean-continent boundary being located at infinity from the ridge axis. We then model the transient regime as the ocean-continent boundary moves away from the ridge axis. At high spreading rate, the steady-state regime at the ridge axis is reached in less than $1 \mathrm{Ma}$ (in other words, the proximity of the continent does not affect anymore the ridge thermal regime). In the slow spreading case, thermal equilibrium at the ridge axis is reached within $3 \mathrm{Ma}$. Even though melt production rates decrease rapidly with distance from the ridge, melt extraction may not be limited to the ridge axis itself. The lateral dimension of the melting region is still a matter of debate (e.g. Scott and Stevenson, 1989; Cordery and Morgan, 1993). It may reach several tens of kilometres, the melt then being focused towards the ridge axis (Spiegelman and Mc Kenzie, 1987). In terms of volume, however, melting models seem to indicate that about 80 to $90 \%$ of the melt that will contribute to the oceanic crust genesis is produced within 20 to $30 \mathrm{~km}$ of the ridge axis. For the Ligurian Sea section, steady-state regime over such distances will be reached within $2 \mathrm{Ma}$ at high spreading rate $(40 \mathrm{~mm} / \mathrm{a})$; at lower spreading rate $(18.5 \mathrm{~mm} / \mathrm{a})$, it may take more than $4 \mathrm{Ma}$ to establish a permanent thermal regime (Fig. 11). The total oceanic basin width would then be 80 to $100 \mathrm{~km}$ in both cases. Above this width, lateral conduction towards continent does not affect the temperature field anymore in the area where melt extraction is maximum. Notice that we discuss here the area where melt extraction is maximum, and not the total width of the melting region which may reach 80 to $100 \mathrm{~km}$ (Cordery and Morgan, 1993).

The width of the oceanic domain along the modelled Ligurian Sea section is between 60 and $80 \mathrm{~km}$. A first conclusion is that lateral conduction cannot be neglected, in particular if spreading was slow. Part of the anomalous oceanic thickness may be the result of side heat loss towards both continental masses (Provence and Corsica). Northward, lateral cooling during rifting may even have been sufficiently large to prevent large-scale melting and the formation of oceanic crust. For similar stretching factor and duration of rifting, the critical total basin width may be of the order of 70-100 km (Alvarez et al., 1984), which is about the size of the northernmost Ligurian Sea Basin. Notice that along section F, crustal thickness is clearly too thick to be compatible with an oceanic origin (Fig. 8). Three coeval effects will act to lower considerably magma supply:

- low spreading rate due to the proximity of the pole of opening;

- low potential temperature, as discussed previously;

- high lateral conduction due to the small basin width.

Oceanic crust produced, if any, would necessary be very thin. The northernmost Ligurian Sea is thus most probably floored with thinned continental crust.

An important implication of our thermal modelling is that thin abnormal oceanic crust formed during the early stage of oceanic spreading can be found within 40 to $50 \mathrm{~km}$ of the ocean-continent boundary. Variability of oceanic crust thickness is thus expected to be found not only along strike, as an effect of a narrowing basin towards the Ligurian Sea, but also across, close to the ocean-continent boundary. In the following sections, we first discuss estimates of the opening rate of the LiguroProvençal Basin, since it is one of the important parameters controlling melting and oceanic crust genesis. We then examine the early oceanic stage leading to the formation of oceanic crust close to the ocean-continent boundary. 

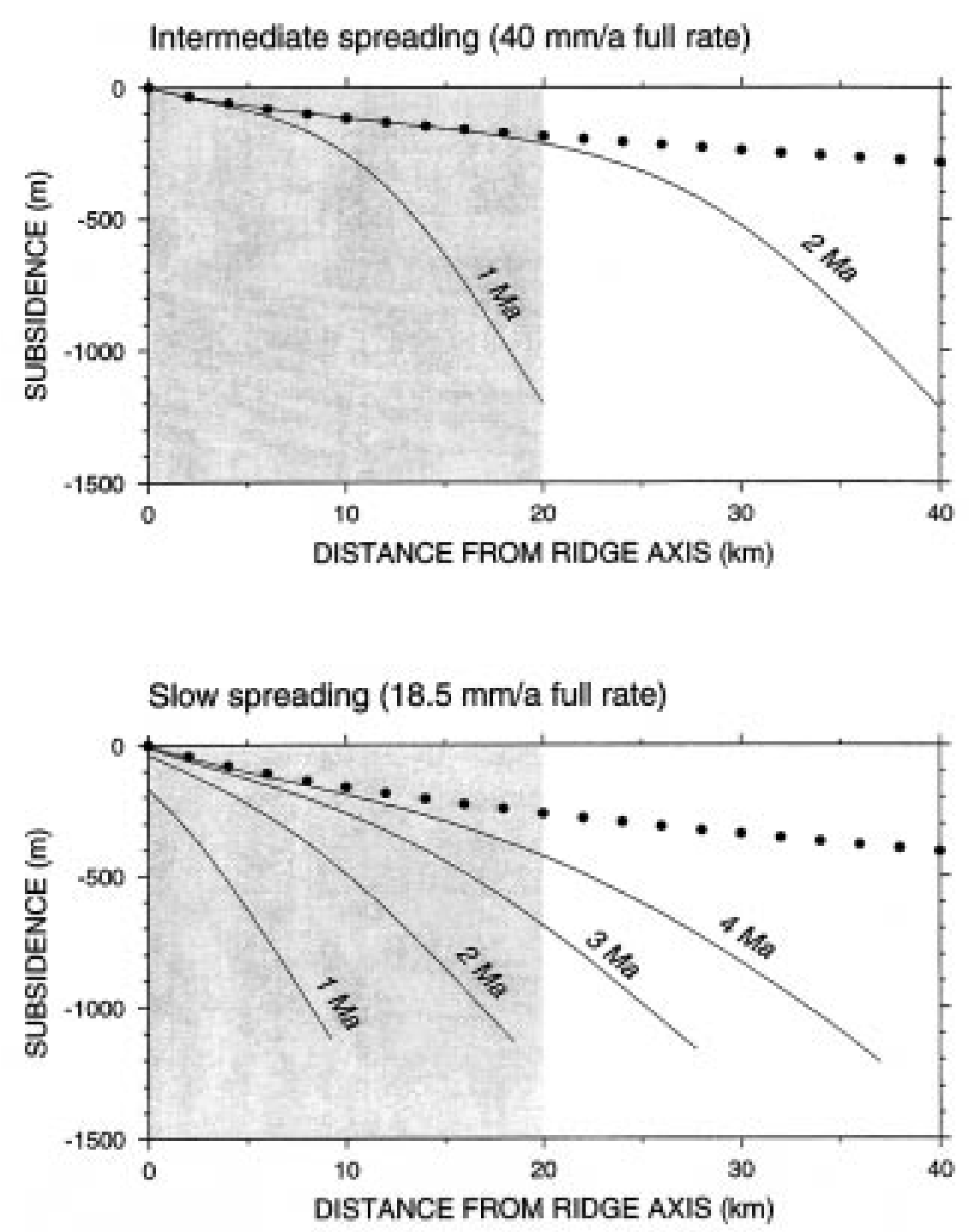

Figure 11a and 11b

a (Top) predicted subsidence of the oceanic lithosphere as a function of proximity of the ocean-continent boundary. An intermediate full spreading rate of $40 \mathrm{~mm} / \mathrm{a}$ is assumed. The ridge axis remains located on the left of the diagram, whereas the ocean-continent boundary is progressively moving away. The $2 \mathrm{D}$ steady-state solution (ocean-continent boundary at infinity) is shown by large dots. Thin lines follow the progressive motion of the continent-ocean boundary away from the ridge axis $1 \mathrm{Ma}$ and $2 \mathrm{Ma}$ after initiation of spreading (modelled section is section E in Fig. 4). The shaded grey area is the location of maximum melt extraction.

b (Bottom) Same as Fig. 11a for slow spreading (18.5 mm/a full rate, equivalent to best value obtained from Fig. 10b).

\subsection{Rate and timing of the Corsica- Sardinia block rotation}

Estimates of the rate and timing of opening of the Liguro-Provençal Basin have been obtained from different types of data: structural restoration of the position of the Sardinia-Corsica block, based on prerotation markers (e.g. Westphal et al., 1976), seismic stratigraphy of pre-rift, syn-rift and post-rift horizons (e.g. Mauffret et al., 1995) age of volcanism in Sardinia (Bellon et al., 1977), paleomagnetic data in Sardinia (Montigny et al., 1981) and Corsica (Vigliotti and Kent, 1990), identification of the magnetic anomalies in the oceanic domain (Burrus, 1984), age of dredged samples in the basin (Réhault, 1981). We focus here on evidences for age and rate of oceanic spreading leading 
to quantitative estimates: age of dredged samples, age of magnetic lineations, age and amount of rotation of Sardinia and Corsica rocks derived from paleomagnetism.

The basement is buried below a thick sedimentary cover over the entire Liguro-Provençal Basin, with the exception of an outcropping ridge in the Ligurian Sea. The southernmost part of the Ligurian Sea is floored with very thin oceanic crust. Crustal thickness gradually increases towards the northeasternmost portion of the Ligurian Sea, which is most probably floored with stretched continental crust (see previous section). Along section F (Fig. 8) the crust is thin at ESP 224 only $(5-6 \mathrm{~km})$. Immediately east of it (ESP 223) runs an axial $\mathrm{N} 30^{\circ}$ trending linear ridge outcropping at its northernmost end (Réhault, 1981; Réhault et al., 1984). The ridge was sampled by dredging and tristanite samples of mid-Miocene age were recovered (18 $\pm 0.5 \mathrm{Ma}$ in Réhault et al.,1984). Recent re-dating would indicate a younger 17 Ma age (Réhault, personal communication, 1996). The tristanite ridge coincides with the central magnetic anomaly high recognised throughout the basin and may thus represent the latest magmatic rocks erupted at the end of the spreading phase (Réhault et al., 1984). The discrepancy between the age of anomaly 6, proposed as the axial anomaly (Burrus, 1984), and the age of the tristanite ridge was already mentioned in Réhaut et al. (1984). Anomaly 6 normal polarity interval lasted $1 \mathrm{Ma}$, from 20.3 to 19.3 Ma (Berggren et al., 1985; Harland et al., 1990). A 17 Ma age would be more compatible with anomaly 5C (three triplets closely spaced in time between 16.2 and $17 \mathrm{Ma}$ ) rather than anomaly 6 . The alternative is that the tristanite ridge erupted after cessation of spreading. Then the positive magnetic anomaly of the ridge, aligned with the positive axial anomaly of the basin, would be fortuitous.

Additional constraints are given by the timing of the rotation of the Sardinia-Corsica block. The amount of Tertiary rotation has been widely debated. Apart from structural evidences based on a common geological history of the Sardinia-Corsica block and the Provençal mainland (e.g. Westphal et al., 1976), paleomagnetic measurements allowed various determinations of the amount and timing of the rotation. Data used range from paleomagnetic measurements on the Tertiary volcanic rocks of Sardinia (Bellon et al., 1977; Edel and Lörtscher, 1977; Edel, 1979; Montigny et al., 1981), aeromagnetic measurements over Sardinia
(Galdeano and Ciminale, 1987), and finally paleomagnetic study of the Tertiary sediments from Corsica (Vigliotti and Kent, 1990), since Tertiary calc-alkaline volcanism is absent there. Different data sets consistently point to a 30 to $40^{\circ}$ counterclockwise rotation of the Sardinia-Corsica block with respect to stable Europe. The timing of the rotation, however, remains uncertain. Dating relies both on $\mathrm{K}-\mathrm{Ar}$ age determinations of the Sardinia andesitic and ignimbritic suite, compiled in Montigny et al. (1981), and Miocene fossiferous limestones of the Neogene basins of Corsica (Vigliotti and Kent, 1990). Both sets of data are apparently conflicting. Montigny et al. argue for a 20.5 to $19 \mathrm{Ma}$ (early Burdigalian) rapid rotation. This is the solution retained by Burrus (1984) to identify magnetic lineations previously delineated by Bayer et al. (1973). Vigliotti and Kent, on the other hand, conclude that a rotation of about $20^{\circ}$ was still to be completed in postBurdigalian-Langhian time. They propose that the rotation did not end before $15 \mathrm{Ma}$ (late Langhian). Their results are controversial not only because they contradict Montigny et al. compilation, but also, as they state themselves, because secondary magnetization cannot be completely ruled out. However, their conclusion is not different from that initially reached by Bellon et al. (1977) from their paleomagnetic study of the Tertiary volcanism of Sardinia.

Paleomagnetic data from Montigny et al. compilation for Sardinia and Vigliotti and Kent data for Corsica are summarised in Figure 12. Notice that we use all data reported in Montigny et al. rather than a selection of the data set. Youngest ages, in particular, were systematically omitted in their original plot. Results obtained from the sedimentary rocks of Corsica by Vigliotti and Kent are actually not incompatible with Sardinian paleomagnetic measurements (see also Vigliotti and Langenheim, 1995). Although scattering for the Sardinia volcanic rocks is high, it is clear that all rocks, regardless of their ages, show a westward oriented magnetization. Taking into account the apparent polar wander path for Eurasia, the Miocene pole position predicts a $+7^{\circ}$ paleomagnetic declination at the location of the Sardinia-Corsica block (Vigliotti and Kent, 1990). The conclusion is that almost none of the observed sites, in the range 35 to $15 \mathrm{Ma}$, remained stable with respect to Eurasia. Although a rapid rotation 


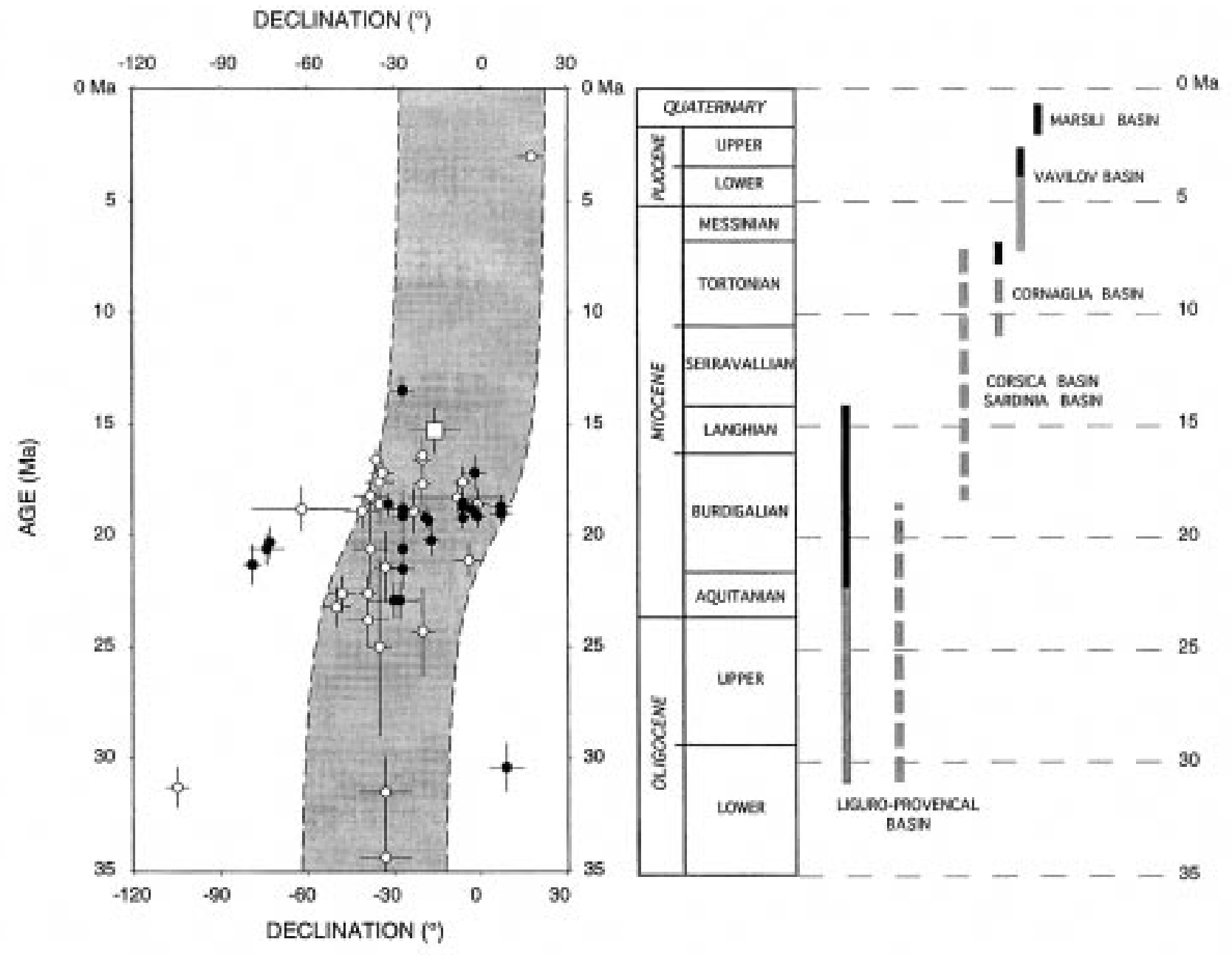

Figure 12

Paleomagnetic data for the Tertiary volcanic rocks of Sardinia (after Montigny et al. 1981; filled dots: normally magnetised; open dots: reversely magnetised) and for the Miocene sedimentary rocks of Corsica (square symbol; after Vigliotti and Kent, 1990). Timing and western Mediterranean Basin opening is shown on the right (dark line: oceanic spreading; grey lines: continental rifting, dashed if not well constrained).

cannot be completely ruled out, a much slower rotation ending in Langhian or Serravalian time would still be compatible with the paleomagnetic data.

Magnetic anomalies interpretation in the oceanic domain is rather inconclusive. The well lineated axial positive anomaly is bounded by one additional positive anomaly on both sides, so that only three anomalies are available for age identification. Considering the set of possible anomalies in the range 25 to $10 \mathrm{Ma}$, most of which are more or less regularly spaced in time every $1 \mathrm{Ma}$, several interpretations are possible. The recognition of the axial anomaly as anomaly 6 (20 Ma) is clearly not compatible with available paleomagnetic data. If the identification of the Late Burdigalian horizon throughout the basin is correct (Mauffret et al., 1995), then the oceanic crust cannot be younger than 16 Ma. Further, onlapping of this horizon on the basement in the axial part of the basin would still have to be proved. Could this horizon be younger, and the Late Burdigalian be deeper? A possible deeper candidate for the Late Burdigalian horizon is present on the ECORS seismic line (horizon X in de Voogd et al., 1981). This horizon is onlapping the acoustic basement a few tens of kilometres away from the inferred 
location of the fossil ridge. Stratigraphic correlation of the Late Burdigalian from GLP2 well (close to ESP 202 on the upper Gulf of Lion margin) to the deep basin would then have to be reconsidered.

The exact age of oceanic spreading in the LiguroProvençal Basin is thus still open to discussion. Cessation of spreading in Late Burdigalian time (16.5 Ma) would be more or less compatible with paleomagnetism, stratigraphic correlations and age of the tristanite ridge. Paleomagnetism alone would tend to indicate an even younger Langhian age (14 Ma?). Calc-alkaline volcanic rocks erupted in Sardinia until $13 \mathrm{Ma}$ (Bellon et al., 1977), indicating that subduction was still going on beneath and that the source for volcanism moved away not before that time (possibly in relation with opening of the Tyrrhenian Basin). Notice that the heat flow in the axial part of the basin is well above $120 \mathrm{~mW} / \mathrm{m}^{2}$, which is the theoretical value for a $15 \mathrm{Ma}$ aged basin. Even in the more conservative hypothesis, oceanic spreading between $23 \mathrm{Ma}$ (post syn-rift Early Aquitanian deposits) and 16.5 Ma (pre-Late Burdigalian) requires to reconsider spreading rate estimates. The width of the oceanic domain along the ECORS line (section A, Fig. 8) is between $150 \mathrm{~km}$ (Mauffret et al., 1995) and $230 \mathrm{~km}$ (Burrus, 1984 or Réhault et al., 1984). Since no differential rotation was found in the paleomagnetic data between 30 and $23 \mathrm{Ma}$, most of the rotation was thus achieved during the oceanic spreading phase (Bellon et al., 1977; Burrus, 1984). A small oceanic domain, less than $200 \mathrm{~km}$ wide, can then be excluded. This would locate the pole of rotation too close (somewhere in the southern Ligurian Sea) to reach the $40^{\circ}$ rotation of the CorsicaSardinia block. A self-consistent solution is obtained if the oceanic width is $230 \pm 20 \mathrm{~km}$. The pole of rotation is found $330 \mathrm{~km}$ away, somewhere in the Gulf of Genoa, close to the location discussed previously. The mean full spreading rate would then be $30 \pm 5 \mathrm{~mm} / \mathrm{a}$, about half the value assumed in Burrus (1984).

Plate separation rates during rifting can be estimated from the amount of stretching across extended conjugate margins. Assuming that the volume of continental crustal rocks remained constant during rifting, calculations for section A (Fig. 9) indicate about $150 \pm 30 \mathrm{~km}$ of total continental extension (i.e. displacement of Sardinia; similar estimates are found in Le Douaran et al., 1984). Taking into account the duration of rifting (7-10 Ma), the mean plate separation rate during rifting was then $20 \pm 7 \mathrm{~mm} / \mathrm{a}$, to be compared to $30 \pm 5 \mathrm{~mm} / \mathrm{a}$ during spreading. We thus favour a continuous extension mechanism throughout the basin history, rather than a sudden pulse of oceanic accretion. Extension in the Liguro-Provençal Basin was then relieved by the opening of the Tyrrhenian Basin. Although rifting in the Tyrrhenian Basin may have started as early as Lower Miocene (post lowerBurdigalian?, Sartori, 1990), the entire basin was not rifted until Tortonian (9 Ma, Sartori, 1990; Kastens, Mascle et al., 1990). Extension was however already active in Alpine Corsica in Late Oligocene or Lower Miocene time, since ductile extension there ended with the deposition of well dated Burdigalian limestones in Corsica and Langhian sediments in the Corsica Basin (Jolivet et al., 1990, 1994). During Pliocene, oceanic crust was produced in two small oceanic basins (Kastens, Mascle et al., 1990), the Vavilov Basin (possibly spreading in Early Pliocene time) and Marsili Basin (younger than $2 \mathrm{Ma}$ ). The recent Médée survey revealed that the toe of the Calabrian prism in the Ionian Sea is not active anymore (Le Pichon et al. submitted to Earth Planet. Sci. Lett.), indicating that extension in the Tyrrhenian Sea may have recently ceased (notice that post-spreading volcanism may be active with little or no extension, as found in many of the back-arc basins of the West Pacific).

Drilling results in the Tyrrhenian Sea (Kastens, Mascle et al., 1990) are compatible with the outward arc migration model of Malinverno and Ryan (1986) which emphasises the role of "rollback" (slab retreat) of the African subduction hinge zone, now located in the Ionian Sea. Restoration of the Tyrrhenian margins to their original widths is somewhat speculative, in particular for the north Calabrian margin. According to Malinverno and Ryan (1986), the total extension (continental stretching plus oceanic spreading) across the basin was $330-350 \mathrm{~km}$, uncertainty amounting to several tens of kilometers. Notice that this is close to the amount of extension obtained on Section A across the Gulf of Lion and Sardinia margin $(380 \pm 50 \mathrm{~km})$, thus suggesting some sort of self-regulating mechanism (such as distance from the subduction front to the back-arc accreting ridge). If we assume that rifting in the Tyrrhenian began $9 \mathrm{Ma}$ ago, then the mean opening rate would be $40 \mathrm{~mm} / \mathrm{a}$. This may be regarded as a maximum value. If we include significant pre-Tortonian rifting, the opening rate may be as low as $20 \mathrm{~mm} / \mathrm{a}$ (Malinverno and Ryan 1986). High oceanic spreading rate was reported in the Marsili Basin (70 to 
$80 \mathrm{~km}$ over a $2 \mathrm{Ma}$ period, $40 \pm 5 \mathrm{~mm} / \mathrm{a}$, Kastens, Mascle et al., 1990), but the exact width of the oceanic domain remains uncertain.

The total extension in the Liguro-Provençal and Tyrrhenian basins, taken along a N135 $5^{\circ}$ azimuth, is thus of the order of $700 \mathrm{~km}( \pm 100 \mathrm{~km})$ since Oligocene time. Opening most probably became effective once the entire Liguro-Provençal Basin was rifted (possibly in Upper Oligocene time). Le Pichon (1984) compared this amount of extension with the present-day length of the Calabrian seismic zone. The seismic slab is $650 \mathrm{~km}$ long, dipping $70^{\circ}$ along a N315 azimuth (Selvaggi and Chiarabba, 1995). Convergence of Africa towards Europe since the Burdigalian may be more than $200 \mathrm{~km}$ in that part of the Mediterranean Sea (Dewey et al., 1989), or $150 \mathrm{~km}$ taken along the azimuth of the slab. The remaining $500 \mathrm{~km}$ can thus be directly compared to the amount of extension in the Western Mediterranean Basins. The length of the slab is clearly too long compared to the amount of extension in the Tyrrhenian Basin only. If the Liguro-Provençal Basin is included, then total extension becomes greater than the length of the seismic slab. Le Pichon (1984) concluded that part of the slab (the last $200 \mathrm{~km}$, subducted in Upper Oligocene) may now be aseismic following reheating at depth. This may be substantiated by tomographic results (e.g. de Jonge et al., 1994) but resolution becomes poor below $400 \mathrm{~km}$ depth.

The succession of basins opening thus suggests a continuum of extension since Oligocene time, with progressive south-eastward migration of basins formation following rollback of the African hinge zone as proposed by Malinverno and Ryan (1986). We suggest that the time gap between opening of the Liguro-Provençal Basin and stretching of the Tyrrhenian Basin should be reconsidered. Cessation of spreading in the Liguro-Provençal Basin 19 Ma ago (as generally assumed), and post-Tortonian rifting of the Tyrrhenian Basin (post $10 \mathrm{Ma}$ ) would imply high velocity African trench retreat in the early stage $(>60 \mathrm{~mm} / \mathrm{a})$, followed by strike-slip motion for $10 \mathrm{Ma}$ (to accommodate the northward motion of Africa with respect to the CorsicaSardinia-Calabria block then belonging to Europe), and finally subduction again $(>40 \mathrm{~mm} / \mathrm{a})$ during Tyrrhenian opening. We favour a model in which trench retreat proceeded at a more or less constant velocity (30 to $40 \mathrm{~mm} / \mathrm{a}$ ) while consuming the old Ionian oceanic lithosphere. Side continental collisions (in the Northern Apennines, between the Kabylies and Africa, in Sicily) may have slowed down the upper plate motion locally, without affecting significantly subduction motion along the remaining oceanic portions of the Ionian lithosphere driven by slab pull (Le Pichon, 1982; Le Pichon and Alvarez, 1984).

\subsection{Crust at the ocean-continent boundary}

Western portion of section (Figs. 7 and 8 ) is along the ECORS deep-seismic profile and cut across ESP 201 to 209 mid-points. Eastern portion of section $\mathrm{B}$ is close to the CROP deep-seismic line. The two sections illustrate the contrast between the wide and smoothly stretched Gulf of Lion margin and the narrow and abruptly stretched Provençal margin. On both sections a very thin crust $(2-3 \mathrm{~km})$ is found at the base of the lower continental margin (ESP 204 on section A, ESP 211 on section B). Our gravity modelling suggests that thin crust should also be found over the conjugate Sardinian margin (Fig. 4), but no further seismic information is available there.

On the Gulf of Lion margin, the detailed analysis of Pascal et al., (1993), based on $\mathrm{x}-\mathrm{t}$ to $\tau$-p transformations and synthetic $\tau$-p seismograms, provides reliable $\mathrm{P}$-wave velocity structure down to Moho depth. The upper crust over the entire basin, including thin continental and oceanic domains, is characterised by a 5.6 to $5.8 \mathrm{~km} / \mathrm{s}$ velocity layer. The mid-crust velocity increases laterally oceanward from ESP 203 and 212 to ESP 204 and 211 respectively, from 6.2 to $6.6 \mathrm{~km} / \mathrm{s}$. Below the thin crust area is a high velocity layer with velocities ranging from 7.1 to $7.4 \mathrm{~km} / \mathrm{s}$. The thickness of the high velocity layer is maximum at ESP 203 $(2.6 \mathrm{~km})$ and at ESP $212(2.9 \mathrm{~km})$. It reaches $1 \mathrm{~km}$ at ESP 211 and 212. As pointed out by Mauffret et al., (1995), the high velocity layer is apparently not restricted to the very base of the margin but extends oceanward $(0.4 \mathrm{~km}$ thick at ESP 205 and $1.4 \mathrm{~km}$ thick at ESP 206). At the base of the Gulf of Lion margin, the top of the high P-wave velocity body correlates with the oceanward rising of a shallow bright reflector on the ECORS line ("T" reflector in Pascal et al., 1993). The $\mathrm{T}$ reflector comes very close to the top of basement between ESP 211 and 212 (LIGO 4 seismic profile, Pascal et al. 1993). This is also the area of thinnest crust in our gravity inversion. Landward, the T reflector coincides with Moho (Pascal et al., this volume). 
The continent-ocean boundary has been placed at various locations along the ECORS line: close to ESP 203 based on magnetic anomalies (Bayer et al., 1973), between ESP 205 and ESP 206 based on the limit of synrift deposits (Burrus, 1984); Le Douaran et al., 1984), and more recently as far as ESP 206 based mainly on the lack of the high velocity layer beyond this point (Mauffret et al., 1995), typical oceanic layer 3 velocities $(6.8 \mathrm{~km} / \mathrm{s})$ being found at ESP 207. In the latter case, the transitional area (possibly thinned continental crust) would be $100 \mathrm{~km}$ wide.

This crust at the base of the Gulf of Lion shows strong similarities with transitional type crust observed on other non-volcanic margins. Thin crust overlying a high velocity layer is found on the western margin of Iberia (3-4 km thick above a 7.3 to $7.6 \mathrm{~km} / \mathrm{s}$ layer, Whitmarsh et al., 1990; Whitmarsh et al., 1993), in the Tagus abyssal Plain $(2 \mathrm{~km}$ thick above $7.6 \mathrm{~km} / \mathrm{s}$ layer increasing to $7.9 \mathrm{~km} / \mathrm{s}$ towards Moho, Pinheiro et al., 1992) and its conjugate Newfoundland margin off Grand Banks (2-3 km thick above 7.2 to $7.7 \mathrm{~km} / \mathrm{s}$ layer, Reid, 1994), accross Southwest Greenland margin $(2.5 \mathrm{~km}$ thick above 7.0 to $7.6 \mathrm{~km} / \mathrm{s}$ layer, Chian and Louden, 1994) and its conjugate Labrador margin $(1-2 \mathrm{~km}$ thick above a 6.4 to $7.7 \mathrm{~km} / \mathrm{s}$ layer, Chian et al., 1995) On the southern Newfoundland margin the high velocity body is limited by one or two landward dipping reflectors rising to basement surface seaward and connecting to Moho landward (Keen and de Voogd, 1988; Reid, 1994). The similarity with the T reflector of the Gulf of Lion is striking.

The origin of the high velocity lower crust on nonvolcanic margins (underplating or serpentinite?) and the nature of the thin overlying crust is still debated (Chian et al., 1995; Srivastava and Roest, 1995). Further discussion is beyond the scope of this paper, although much could be learned by integrating the Gulf of Lion data into a much broader review of tectonic processes at non-volcanic margins. A few conclusions can however be drawn from the preceding sections. Underplating is very unlikely. Taking into account cooling during rifting (which lasted at least $7 \mathrm{Ma}$ ) and low initial mantle temperature (30 to $50^{\circ} \mathrm{C}$ below normal), the amount of melt generated during rifting was probably very small as for other non-volcanic margins (Bown and White, 1995a). The thin crust flooring the lower margin of the Gulf of Lion as well as the lower margin of Sardinia may be of oceanic origin. Thermal modelling (Fig. 11) demonstrates that the width of abnormal thin oceanic crust may reach 40 to $50 \mathrm{~km}$, which is about the right amount obtained by gravimetric modelling and seismic refraction (see sections in Figure 8).

\section{CONCLUSIONS}

The deep structure of the Liguro-Provençal Basin is discussed using gravity as an additional control to existing sparse seismic data. The main results can be summarised as follows:

- 3D gravity inversion using Fourier transforms is a potential powerful tool to obtain a reliable geometry of the Moho discontinuity in areas where only sparse deep seismic informations are available. Free parameters in the inversion (Moho reference depth and crust-mantle density contrast) can be obtained through least squares minimisation of the standard deviation of the gravimetric solution at some given reference points where the Moho is seismically constrained, such as ESP data. The misfit in the Liguro-Provençal Basin is about $2 \mathrm{~km}$ for 12 to $30 \mathrm{~km}$ Moho depth range. Corrections for variable crust density and variable heat flow distribution can also be included, although in the particular case of the Liguro-Provençal Basin they do not improve significantly the solution.

- The oceanic crust thickness in the Liguro-Provençal Basin is smaller than usually reported in open oceans $(5 \pm 1 \mathrm{~km}$ instead of $7 \pm 1 \mathrm{~km})$. We show that the thin oceanic crust is compatible with $1280^{\circ} \mathrm{C}$ potential mantle temperature, which is $30^{\circ} \mathrm{C}$ to $50^{\circ} \mathrm{C}$ below normal. Low temperature is also responsible for the abnormal subsidence of the deep LiguroProvençal Basin. Thin crust and high subsidence have been reported in other marginal basins, in particular in the West Pacific. Subduction of cold material may be responsible for significant cooling at depth. However, thermal conduction is slow and would probably require a long history of subduction. For the same reason (slow conductive process), lithospheric thickening coeval with orogen formation and prior to extension may be a more efficient way to lower temperatures at mantle depth.

- The decrease of oceanic crust thickness towards the Ligurian Sea to values as small as $2 \mathrm{~km}$ indicates a very low magma supply. The temperature field there is affected by two different effects, both of conductive origin: heat is lost laterally towards the adjacent continents (Provençal margin and Corsica), 
thus preventing large-scale melting even during oceanic accretion; rate of opening in the Ligurian Sea falls below the critical $15 \mathrm{~mm} / \mathrm{a}$ full spreading rate below which magma supply becomes negligible. An important implication is that in the northern Ligurian Sea, where lateral conduction is maximum and distance to the pole of opening minimum, the crustal thickness is too thick to be of oceanic origin.

- The thin crust at the ocean-continent boundary may be oceanic crust produced in the very early stage of oceanic spreading, as proposed for some of the nonvolcanic Atlantic margins. Several million of years are required to establish a steady-state thermal regime at the ridge axis, due to lateral cooling towards unextended continental areas. The lower margin of the Gulf of Lion has actually many of the characteristics encountered on other non-volcanic margins: tilted blocks rooted on a seaward dipping reflector, high P-velocity body bounded to the top by a landward dipping reflector, and connecting at depth with Moho towards the continent, very thin crust in the transitional region from thinned crust to oceanic crust.

- A close re-examination of magnetic data (paleomagnetic data and magnetic lineations) shows that the exact age of oceanic spreading, as well as the opening rate, is still debatable. Cessation of spreading in Late Burdigalian time (16.5 Ma) would be a reasonable compromise between somewhat divergent paleomagnetism, stratigraphic interpretation and age of dredged samples data. An even younger age cannot be completely ruled out. In any case, we favour a constant and slow opening at a rate of $5^{\circ} / \mathrm{Ma}$ rather than a sudden pulse of oceanic accretion.

- The new Moho depth map is used to estimate the amount of extension across the Liguro-Provençal Basin. Comparison with the Tyrrhenian Basin and length of the Calabrian slab suggests a continuous extension mechanism since Oligocene time driven by the African trench retreat, following Malinverno and Ryan (1986) model. It is suggested that the process continued uninterrupted until recent time, unless drastic velocity changes occurred at the subduction zone where the old Ionian oceanic lithosphere was being consumed.

\section{ACKNOWLEDGEMENTS}

This paper is within the framework of the Integrated Basin Studies (IBS) program. We are grateful to
G. Pascal for his helpful comments on reflection and refraction data interpretation. Stimulating lectures given by X. Le Pichon at Collège de France in 1996 helped in clarifying some of the ideas developed here. We thank our colleagues who made available to us some of their unpublished data, in particular A. Mauffret for his digital file of sediment thickness around the Gulf of Lion margin and C. Truffert for some new processed maps of the magnetic field.

\section{REFERENCES}

Alvarez F., J. Virieux, and X. Le Pichon (1984), Thermal consequences of lithosphere extension over continental margins: the initial stretching phase. Geophysical Journal of the Royal Astronomical Society, 78, 389-411.

Anguy Y., B. Damotte and F. Roure (1991), Tirs sismiques latéraux complémentaires au profil ECORS-Pyrénées : apport à la connaissance de l'architecture profonde de la chaîne. Comptes rendus de l'Académie des Sciences, sér. D, Paris, 313, 677-684.

Arthaud F., M. Ogier and M. Séguret (1980), Géologie et géophysique du golfe du Lion et de sa bordure nord. Bulletin du Bureau de recherches géologiques et minières, 1, 175-193.

Banda E., J. Ansorge, M. Boloix and D. Cordoba (1980), Structure of the crust and upper mantle beneath the Balearic Islands (western Mediterranean). Earth and Planetary Science Letter, 49, 219-230.

Bayer R., J.L. Le Mouel and X. Le Pichon (1973), Magnetic anomaly pattern in the western Mediterranean. Earth and Planetary Science Letters, 19, 168-176.

Bellon H., C. Coulon and J.B. Edel (1977), Le déplacement de la Sardaigne. Synthèse des données géochronologiques, magmatiques et paléomagnétiques. Bulletin de la Société géologique de France, 7, 825-831.

Berggren W.A., D.V. Kent, J.J. Flynn and J.A. Van Couvering (1985), Geological Society of America Bulletin, 96, 107-118.

Bessis F. (1986), Some remarks on the study of subsidence of sedimentary basins. Application to the Gulf of Lion margin (western Mediterranean). Marine and Petroleum Geology, 3, 37-63.

Bown J.W. and R.S. White (1994), Variation with spreading rate of oceanic crustal thickness and geochemistry. Earth and Planetary Science Letters, 121, 435-449.

Bown J.W. and R.S. White (1995a). Effect of finite extension rate on melt generation at rifted continental margins. Journal of Geophysical Research, 100, 18011-18029.

Bown J.W. and R.S. White (1995b). Finite duration rifting, melting and subsidence at continental margins. In: Rifted Continent-Ocean Boundaries. Tyrone, M. and Talwani, M. (eds). Banda, E., Kluwer Academic Press, Netherlands, 31-54.

Burrus J. (1984), Contribution to a geodynamic synthesis of the Provençal Basin (north-western Mediterranean). Marine Geology, 55, 247-269.

Burrus J. (1989), Review of geodynamic models for extensional basins. The paradox of stretching in the Gulf of Lion (northwest Mediterranean). Bulletin de la Société géologique de France, 8, 377-393. 
Chen Y.J. (1992), Oceanic crustal thickness versus spreading rate. Geophysical Research Letters, 19, 753-756.

Chian D. and K.E. Louden (1994), The continent-ocean crustal transition across the Southwest Greenland margin. Journal of Geophysical Research, 99, 9117-9136.

Chian D. and I. Reid (1995), Crustal structure of the Labrador Sea conjugate margin and implications for the formation of nonvolcanic continental margins. Journal of Geophysical Research, 100, 24239-24253.

Choukroune P. and E. Team (1989), The ECORS Pyrenean deep seismic profile reflection data and the overall structure of an orogenic belt. Tectonics, 8, 23-39.

Choukroune P., F. Roure, B. Pinet and E.P. Team (1990), Main results of the ECORS Pyrenees profile. Tectonophysics, 173, 411-423

Cordery M.J. and J.P. Morgan (1993), Convection and melting at mid-ocean ridges. Journal of Geophysical Research, 98, 19477-19503.

Cowie P.A. and G.D. Karner (1990), Gravity effect of sediment compaction: examples from the North Sea and the Rhine Graben. Earth and Planetary Science Letters, 99, 141-153.

Danobeitia J.J., M. Arguedas, J. Gallart, E. Banda and J. Makris (1992), Deep crustal configuration of the Valencia trough and its Iberian and Balearic borders from extensive refraction and wideangle reflection seismic profiling. Tectonophysics, 302, 37-55.

De Jonge M.R., M.J.R. Wortel, and W. Spakman (1994), Regional scale tectonic evolution of the seismic velocity structure of the lithosphere and the upper mantle: the Mediterranean region. Journal of Geophysical Research, 89, 12091-12108.

Della Vedova B., F. Lucazeau, V. Pasquale, G. Pellis and M. Verdoya (1995), Heat flow in the tectonic provinces crossed by the southern segment of the European Geotraverse. Tectonophysics, 244, 57-74.

De Voogd B., R. Nicolich, J.L. Olivet, F. Fanucci, J. Burrus, A. Mauffret, G. Pascal, A. Argnani, J.M. Auzende, M. Bernabini, C. Bois, L. Carmignani, A. Fabbri, I. Finetti, A. Galdeano, C. Gorini, P. Labaume, D. Lajat, P. Patriat, B. Pinet, J. Ravat, F. Ricci Lucchi, and S. Vernassa (1991). First deep seismic reflection transect from the Gulf of Lion to Sardinia (ECORS-CROP profiles in western Mediterranean). In: Continental lithosphere: deep-seismic reflections, American Geophysical Union, 265-274.

Dewey J.F., M.L. Helman, E. Turco, D.H.W. Hutton and S.D. Knott (1989), Kinematics of the western Mediterranean. In: Alpine tectonics. Geological Society, Coward, M.P., Dietrich, D. and Park, R.G. (eds), Special Publications, London, 45, 265-283.

Edel J.B. (1979), Paleomagnetic study of the Tertiary volcanics of Sardinia. Journal of Geophysics, 45, 259-280.

Edel J.B. and A. Lörtscher (1977), Paléomagnétisme du volcanisme tertiaire de Sardaigne. Nouveaux résultats et synthèse. Bulletin de la Société géologique de France, $\mathbf{7}$, 815-824.

Egger A. (1992), Lithospheric structure along a transect from the northern Apennines to Tunisia derived from seismic refraction data. PhD Thesis, Swiss Federal Institute of Technology, Zürich.

Egger A., M. Demartin, J. Ansorge, E. Banda, and M. Maiestrello (1988), The gross structure of the crust under Corsica and Sardinia. Tectonophysics, 150, 363-389.

Galdeano A. and M. Ciminale (1987), Aeromagnetic evidence for the rotation of Sardinia (Mediterranean Sea): comparison with the paleomagnetic measurements. Earth and Planetary Science Letters, 82, 193-205.

Gallart J., M. Daignières, E. Banda, E. Surinach and A. Hirn (1980), The eastern Pyrenean domain: lateral variations at crustmantle level. Annales Geophysicae, 36, 2, 141-158.

Giese P., C. Morelli, and L. Steinmetz (1973), Main features of crustal structure in western and southern Europe based on data of explosion seismology. Tectonophysics, 20, 367-379.

Gorini C. (1993), Géodynamique d'une marge passive: le golfe du Lion (Méditerranée occidentale). Thèse de $3^{e}$ cycle, Toulouse.

Harland W.B., R.L. Armstrong, A.V. Cox, L. Craig, A.G. Smith, and D.G. Smith (1990), A geological time-scale 1989, Cambridge University Press, New York.

Jackson H.R., I. Reid and R.K.H. Falconer (198), Crustal structure near the Arctic mid-ocean ridge. Journal of Geophysical Research, 87, 1773-1783.

Jolivet L., J.M. Daniel and M. Fournier (1991), Geometry and kinematics of ductile extension in alpine Corsica. Earth and Planetary Science Letters, 104, 278-291.

Jolivet L., C. Truffert and B. Goffe (1994), Exhumation of deep crustal metamorphic rocks and crustal extension in arc and backarc regions. Lithos, 33, 3-30.

Kastens K., J. Mascle et al. (1990), The geological evolution of the Tyrrhenian Sea: an introduction to the scientific results of ODP Leg 107. In: Proceedings of the Ocean Drilling Program, Scientific Results. Kastens, K., Mascle, J. et al. (eds). College Station, TX (Ocean Drilling Program), 107, 3-26.

Keen C.E. and B. de Voogd (1988), The continent-ocean boundary at the rifted margin off eastern Canada: new results from deep seismic reflection studies. Tectonics, 7, 107-124.

Le Douaran S., J. Burrus and F. Avedik (1984), Deep structure of the north-western Mediterranean Basin: Results of a two-ship seismic survey. Marine Geology, 55, 325-345.

Le Pichon X.( 1982), Land-locked oceanic basins and continental collision: the Eastern Mediterranean as a case example. In: Mountain-Building Processes. Hsü, K. (ed). Academic Press, London, 201-211.

Le Pichon X. (1984), The Mediterranean Sea. In: Origin and History of Marginal and Inland Seas. Proceedings of the 27th International Geological Congress, VNU Science Press, Amsterdam, 23, 189-222.

Le Pichon X. and F. Alvarez (1984), From stretching to subduction in back-arc regions: dynamic considerations. Tectonophysics, 102, 343-357.

Mc Kenzie D. (1978), Some remarks on the development of sedimentary basins. Earth and Planetary Science Letters, 40, 25-32.

Mc Kenzie D. and M.J. Bickle (1988), The volume and composition of melt generated by extension of the lithosphere. Journal of Petrology, 29, 625-679.

Maillard A. A. Mauffret, A.B. Watts, M. Torné, G. Pascal, P. Buhl and B. Pinet (1992), Tertiary sedimentary history and structure of the Valencia trough (western Mediterranean). Tectonophysics, 203, 57-75.

Malinverno A. and W.B.F. Ryan (1986), Extension in the Tyrrhenian Sea and shortening in the Apennines as result of arc migration driven by sinking of the lithosphere. Tectonics, $\mathbf{5}$, 227-245. 
Mauffret A., A. Maillard, G. Pascal, M. Torne, P. Buhl and B. Pinet (1992), Long-listening multichannel profiles in the Valencia trough (Valsis 2) and the Gulf of Lion (ECORS): a comparison. Tectonophysics, 203, 285-304.

Mauffret A., G. Pascal, A. Maillard and C. Gorini (1995),. Tectonics and deep structure of the north-western Mediterranean Basin. Marine and Petroleum Geology, 12, 645-666.

Montigny R., J.B. Edel and R. Thuizat (1981), Oligo-Miocene rotation of Sardinia: K-Ar ages and paleomagnetism data of tertiary volcanics. Earth and Planetary Science Letters, 54, 261-271.

Moussat E (1983), Évolution de la mer Tyrrhénienne centrale et orientale et de ses marges septentrionales en relation avec la néotectonique de l'arc calabrais. Thèse de $3^{e}$ cycle, université Pierre et Marie Curie, Paris.

Nafe J.E. and C.L. Drake (1963), Physical properties of marine sediments. In: The Sea, M.N. Hill (Ed.) Interscience Publishers, 3, 794-815.

Parker R.L. (1973), The rapid calculation of potential anomalies. Geophysical Journal of the Royal Astronomical Society, 31, 447-455.

Pascal G., M. Torné, P. Buhl, A.B. Watts and A. Mauffret (1992), Crustal and velocity structure of the Valencia trough (western Mediterranean). Part II: detailed interpretation of five expanded spread profiles. In: Geology and Geophysics of the Valencia Trough, Western Mediterranean., Banda, E. and Surinach, P. (eds) Tectonophysics, 203, 285-304.

Pascal G., A. Mauffret and P. Patriat (1993), The ocean-continent boundary in the Gulf of Lion from analysis of expanding spread profiles and gravity modelling. Geophysical Journal International, 113, 701-726.

Pascal G., C. Truffert, M. Ramaswany and M. Talwani. Formation and evolution of the Gulf of Lion margin: evidence from deep-seismic and wide-angle reflection data. Bulletin de la société géologique de Londres, in press.

Pinheiro L.M., R.B. Whitmarsh and P.R. Miles (1992), The ocean-continent boundary off the western continental margin of Iberia, II, Crustal structure in the Tagus Abyssal Plain. Geophysical Journal International, 109, 106-124.

Réhault J.P. (1981), Évolution tectonique et sédimentaire du bassin ligure (Méditerranée occidentale). Thèse de doctorat d'État, université Pierre et Marie Curie, Paris.

Réhault J.P., G. Boillot and A. Mauffret (1984), The western Mediterranean Basin geological evolution. Marine Geology, 55, 447-477.

Réhault J.P., E. Moussat and A. Fabbri (1987), Structural evolution of the Tyrrhenian back-arc Basin. Marine Geology, 74, 123-150.

Réhault J.P., C. Tisseau, M.F. Brunet and K. Louden (1990), Subsidence analysis on the Sardinian margin and the central Tyrrhenian Basin: thermal modelling and heat flow control; deep structure implications. In: Geophysics of the Mediterranean Basin. J.J. Danobeitia and B. Pinet (eds). Journal of Geodynamics, 269-310.

Reid I. (1994), Crustal structure of a non-volcanic rifted margin east of Newfoundland, Journal of Geophysical Research, 99, 15161-15180.

Reid I. and H.R. Jackson (1981), Oceanic spreading rate and crustal thickness. Marine Geophysical Research, 5, 165-172.

Sandwell D.T. and W.H.F. Smith (1995), Marine Gravity Anomaly from Satellite Altimetry (Map). Geological Data Center, Scripps Institution of Oceanography.
Sapin M. and A. Hirn (1974), Results of explosion seismology in the southern Rhône Valley. Annales Geophysicae, 30, 181-202.

Sartori R. (1990), The main results of ODP Leg 107 in the frame of Neogene to Recent geology of Perityrrhenian areas. In: Proc. ODP, Kastens, K., Mascle, J. et al. (eds). Scientific Results, 107, 715-730.

Scott D.R. and D.J. Stevenson (1989), A self-consistent model of melting, magma migration and buoyancy-driven circulation beneath mid-ocean ridges. Journal of Geophysical Research, 94, 2973-2988.

Selvaggi, G. and C. Chiarabba (1995), Seismicity and P-wave velocity image of the southern Tyrrhenian subduction zone. Geophysical Journal International, 121, 818-826.

Spiegelman M. and D. Mc Kenzie (1987), Simple 2-D models for melt extraction at mid-ocean ridges and island arcs. Earth and Planetary Science Letters, 83, 137-152.

Srivastava S.P. and W.R. Roest (1995), Nature of thin crust across the southwest Greenland margin and its bearing on the location of the ocean-continent boundary. In: Rifted ContinentOcean Boundaries. E. Banda, M. Torné and M. Talwani (eds). Kluwer Academic Press, Netherlands, 95-120.

Steckler M.S. and A.B. Watts (1980), The Gulf of Lion: subsidence of a young continental margin. Nature, 287, 425-429.

Su, W., C.Z. Mutter, J.C. Mutter, and W.R. Buck (1994), Some theoretical predictions on the relationships among spreading rate, mantle temperature, and crustal thickness. Journal of Geophysical Research, 99, 3215-3227.

Talwani M. and M. Ewing (1960), Rapid computation of gravitational attraction of three-dimensional bodies of arbitrary shape. Geophysics, 25, 203-225.

Torne M., G. Pascal, P. Buhl, A.B. Watts and A. Mauffret (1992), Crustal and velocity structure of the Valencia trough (western Mediterranean), Part I. A combined refraction/wide-angle reflection and near-vertical reflection study. Tectonophysics, $\mathbf{2 0 3}$, $1-20$.

Vially R. and P. Trémolières (1996), Geodynamics of the Gulf of Lion. Implications for petroleum exploration. In: Structure and prospects of Alpine basins and forelands. Peri-Tethys Memoir 2, P.A. Ziegler, and F. Horvath, F. (eds). Édition Technip, Paris, 129-158.

Vigliotti L. and D.V. Kent (1990), Paleomagnetic results of Tertiary sediments from Corsica: evidence of post-Eocene rotation. Physics of the Earth and Planetary Interiors, 62, 97-108.

Vigliotti L. and V.E. Langenheim (1995), When did Sardinia stop rotating? New paleomagnetic results. Terra Nova, 7, 424-435.

Watts A.B. and M. Torne (1992a), Subsidence history, crustal structure and thermal evolution of the Valencia trough: a young extensional basin in the western Mediterranean. Journal of Geophysical Research, 97, 20021-20041.

Watts A.B. and M. Torne (1992b), Crustal structure and the mechanical properties of extended continental lithosphere in the Valencia trough (western Mediterranean). Journal of Geological Society of London, 149, 813-827.

Watts A.B., M. Torne, P. Buhl, A. Mauffret, G. Pascal, G. and B. Pinet (1990), Evidence for reflectors in the lower continental crust before rifting in the Valencia trough. Nature, 348, 631-634.

Westphal M., J. Orsini and J. Vellutini (1976), Le microcontinent corsosarde, sa position intiale : données paléomagnétiques et raccords géologiques. Tectonophysics, 30, 141-157. 
White R.S. and D. Mc Kenzie (1989), Magmatism at rift zones: the generation of volcanic continental margins and flood basalts. Journal of Geophysical Research, 94, 7685-7729.

White R., D. Mc Kenzie and R.K. Onions (1992), Oceanic crustal thickness from seismic measurements and rare earth element inversions. Journal of Geophysical Research, 97, 19683-19715.

Whitmarsh R.B., P.R. Miles and A. Mauffret (1990). The oceancontinent boundary off the western continental margin of Iberia, I, Crustal structure at $40^{\circ} 30 \mathrm{~N}$. Geophysical Journal International, 103, 509-531.
Whitmarsh R.B., L.M. Pinheiro, P.R. Miles, M. Recq and J.C. Sibuet (1993), Thin crust at the western Iberia oceancontinent transition and ophiolites. Tectonics, 12, 1230-1239.

Zeyen H.J., E. Banda, J. Gallart, and J. Ansorge (1985), A wide angle seismic reconnaissance survey of the crust and upper mantle in the Celtiberian Chain of eastern Spain. Earth and Planetary Science Letters, 75, 393-402.

Final manuscript received in November 1997 